Article

\title{
Insights into PCDD/Fs and PAHs in Biomass Boilers Envisaging Risks of Ash Use as Fertilizers
}

\author{
Helena Lopes ${ }^{1, *(1)}$ and Susana Proença ${ }^{2}$ \\ 1 National Laboratory of Energy and Geology, Estrada Paço Lumiar, 22, Ed. G, 1649-038 Lisbon, Portugal \\ 2 Institute for Risk Assessment Sciences, Utrecht University, 3512 Utrecht, The Netherlands; s.proenca@uu.nl \\ * Correspondence: helena.lopes@lneg.pt
}

Received: 4 June 2020; Accepted: 16 July 2020; Published: 18 July 2020

\begin{abstract}
Since ashes are a possible source of Persistent Organic Pollutants (POPs) contamination, their application in soils must be subject to more study and control. In this scope, feed residual forest biomasses and biomass ashes, collected along one year in four biomass power stations, were characterized mainly for their polychlorinated dibenzo-p-dioxins and polychlorinated dibenzofurans (PCDD/Fs) and Polycyclic Aromatic Hydrocarbons (PAHs) contents. The biomasses present concerning levels of $\mathrm{Cl}(0.04-0.28 \%)$ that may lead to $\mathrm{PCDD} / \mathrm{Fs}$ formation. The biomasses also contain OCDD (29-260 ng/ $/ \mathrm{kg})$ and 1,2,3,4,6,7,8-HpCDD (35 ng/kg) that may contribute to increased Toxic Equivalents (TEQs) of ashes, possibly involving dechlorination and ash enrichment mechanisms. While the $\mathrm{WHO}_{2005}$-TEQs in bottom ashes (14-20 ng TEQ/kg) reaches the proposed limit $(20 \mathrm{ng}$ $\mathrm{TEQ} / \mathrm{kg}$ ) for ash use as fertilizers, in fly ashes (35-1139 $\mathrm{ng}$ TEQ $/ \mathrm{kg}$ ) the limit is exceeded. PAHs are below $0.02 \mathrm{mg} / \mathrm{kg}$ in bottom ashes and $1.5-2.5 \mathrm{mg} / \mathrm{kg}$ in fly ashes, complying with the proposed limit of $6 \mathrm{mg} / \mathrm{kg}$. As bottom and fly ash streams may contain different ash flows, a clear definition of ash mixes is required. Correlations between unburned carbon (C), PAHs and PCDD/Fs were not found, which highlights the need for compulsory PCDD/Fs analysis in ashes, independently of their origin, burnout degree or levels of other contaminants. A sensitivity analysis was performed to evaluate the impact of handling non-detected values, which showed more impact for TEQs values close to the proposed regulatory limit of PCDD/Fs. These findings highlight the need to define reporting protocols of analytical results for risk assessments and conformity evaluation.
\end{abstract}

Keywords: residual forest biomass; combustion; ash; fertilizers; PCDD/Fs; PAHs; TEQs; BaP-EQs; non-detected handling; regulatory limits

\section{Introduction}

One of the objectives of the United Nations' Sustainable Development Goals (UN SDGs) is the worldwide minimization of release of chemicals to air, water, and soil [1]. The most recent EU Regulation on Persistent Organic Pollutants (POPs) [2], which recast the previous regulation [3] on the EU POPs Implementation Plan, reinforces the need of reduction and elimination of POPs to protect the environment and human life. This regulation aligns with the United Nations (UN) instruments; the Aarhus Protocol on Long-Range Transboundary Air Pollution on POPs (POPs Protocol) [4], the Stockholm Convention on POPs (POPs Convention) [5] and the Basel Convention on the control of transboundary movements of hazardous wastes and disposal [6].

Polycyclic Aromatic Hydrocarbons (PAHs), polychlorinated biphenyls (PCBs) and polychlorinated dibenzo-p-dioxins (PCDDs) and polychlorinated dibenzofurans (PCDFs), also named as dioxins or $\mathrm{PCDD} / \mathrm{Fs}$, are among the dozens of highly toxic POPs envisaged in several regulations. According to annex C of the Stockholm POPs Convention, the PCDD/Fs are considered as "Unintentional" POPs (UPOPs) since they are formed unintentionally in various anthropogenic activities, including "Firing 
installations for wood and other biomass fuels". For waste management, the EU POPs Regulation [2] aligns with the Basel Convention; contaminated wastes with levels of POPs above certain limits, "low POPs content" (LPCL), are "POP wastes" and must be disposed or treated. For PCDD/Fs, the provisional LPCL (expressed as Toxicity Equivalents-TEQ), 15,000 ng TEQ/kg, is considered too high and not protective. In fact, practices such as uncontrolled dumping and unaware spread of contaminated residues in soils (sludge, ashes, etc.) [7-9], highlight the need to define more precautionary limits.

The UNEP Standardized Toolkit [10] was developed within the Stockholm Convention on POPs, for identification and quantification of releases of PCDD/Fs and other UPOPs. Five emission (EF) vectors were considered for several activities: EFair, EFsoil, EFwater, EFproducts and EFresidues, revealing that the greatest dissemination routes for PCDD/Fs are air emissions (45\%), residues, including ashes (34\%), and land accumulation (11\%). Several guidelines on "Best Available Technology/Best Environmental Practices" (BAT/BEPs) were also developed in accordance with article 5 and annex C of the POPs Convention, to prevent formation and release of UPOPs [11]. The BAT/BEP "Guidance/Guidelines for Firing Installations for Wood and Other Biomass Fuels" recommends that combustion of contaminated biomass, such as construction wood waste, should be avoided in biomass furnaces to minimize formation of PCDD/Fs and PAHs. It also specifies that fly ashes from biomass combustion have to be properly landfilled. The implementation of technologies to reduce air emissions from industrial installations according to BAT/BEPs and BREFs [12] of the Industrial Emissions Directive [13] is foreseen to increase amounts and hazardousness of ashes contaminated with POPs.

As very Persistent, very Bioaccumulative and Toxic pollutant (PBT), PCDD/Fs were broadly discussed within the EU "Strategy for a Non-Toxic Environment"; a sub-study on very persistent chemicals [14] highlights the risks of their accumulation, concentration and dispersion, namely through reuse/recycling of streams within the Circular Economy. These concerns will be addressed in the upcoming European Green Deal framework [15].

The Community Strategy for PCDD/Fs and PCBs [16] recognized that bioaccumulation via the food chain is the most critical pathway of human exposure to PCDD/Fs and PCBs and that contamination of food processing animals and edible plants occurs mainly via uptake from soils. Given the evidence of environmental legacy and threats, [7,8,17-21], PCDD/Fs and PCBs are included in the group of most relevant soil pollutants, among other POPs. For protection of human health, limits of PCDD/Fs in foodstuffs [22] were pushed down to safer values [23], namely for free-range eggs, which are highly sensitive to dioxin effects. Weber et al. [8] evaluated the sources and influence of soils contamination on food safety, for example, $5 \mathrm{ng}$ TEQ/kg of PCDD/Fs + PCBs in soils induces contents above the safe limits in free-range chickens/eggs, exceeding the Tolerable Daily Intake (TDI). Among identified sources, the application of ashes and sludges are referred to as relevant causes of soils contamination. This highlights the urgent need to update soils regulations, as well as regulations and monitoring of products used as fertilizers and pesticides, with protective limits for POPs.

Between 2010 and 2017, the efforts to control greenhouse gases (GHG) resulted in an increase of $70 \%$ and $37 \%$ of biomass used for electricity and heat production, respectively [24]. This may increase pressure on the environment since about $90 \%$ consists of forest biomass. Hence, sustainable principles to increase bioenergy must include proper ash management and protection of soils, incorporating the Stockholm POPs Convention orientations.

Around $10 \%$ of the world primary energy is generated by combustion of biomass, using several combustion technologies, like fluidized bed (FB) systems, grate furnaces (GF) and pulverized combustion (PC) [25]. Combustion processes generate emissions of air pollutants and fine particulate matter (PM), and result in several ash streams like bottom or bed ash, boiler ash, filter ash and electrostatic precipitators (ESP) fly ash. Ash characteristics depend on the biomass used and combustion technology, as well as on air pollution control devices (APCDs) and ash collection strategy. Biomass ashes are essentially composed of inorganic elements contained in the fuels, plus extraneous minerals from adhering soil or sand, minerals used as bed material in the case of FB 
systems, and, eventually, additives and sorbents added for pollution control. For clean woody biomass ashes, mostly composed of $\mathrm{Si}, \mathrm{Ca}, \mathrm{Mg}, \mathrm{K}, \mathrm{P}, \mathrm{Na}, \mathrm{Al}, \mathrm{Fe}, \mathrm{Cl}$ and $\mathrm{S}$, only traces of heavy metals are usually present, however, co-combustion with wastes may raise toxic metals to concerning levels [26-30]. Ash may also contain many Products of Incomplete Combustion (PICs), including POPs, of which the most concerning are PCDD/Fs, PAHs, and PCBs [31-35].

The reutilization of ashes is highly attractive for a great variety of purposes, driven by management needs and circular economy $[36,37]$. Interest of using biomass ashes as soil fertilizers (a traditional practice) has been broadly investigated, mainly concerning physicochemical properties, composition, presence of heavy metals and leachability [38-48]. Some publications address the problem of PAHs [49-53], but usually PCDD/Fs and other organic pollutants are not mentioned or are considered of minor relevance in biomass ashes to be applied in soils. However, the intensive use of biomass ashes may have significant impacts; for example, the application of industrial wood ashes containing 7.4-36 ng TEQ/kg, at 18-38 ton/acre/year, was estimated to increase PCDD/Fs in soils by $0.15-1.53 \mathrm{ng}$ TEQ/kg a year [54]. Bundt et al. [55] also found that wood ash application, containing $16.8 \mathrm{mg} / \mathrm{kg}$ of PAHs and $3.4 \mu \mathrm{g} / \mathrm{kg}$ of PCBs, increased by six-fold the concentrations of PAHs in a forest soil. On the other hand, a decrease of PCBs was observed, possibly due to enhanced solubilization, owing to the ash alkalinity. This may indicate that deeper soil levels and water aquifers may become contaminated with PCBs. A previous paper [56] presented the chemical constitution of biomass ashes, revealing low levels of heavy metals and low mineral leachability. Some TEQs and $\Sigma$ PAHs were also presented to highlight that biomass ash may exhibit POPs contamination, although the EU proposal to regulate the use of ashes as soils fertilizer was not available then.

Despite the low solubility of PCDD/Fs and PAHs, suggesting low environmental availability, it has been shown that leachability of dioxins depends on composition and sorption properties of soils [57]. In fact, Kim and Lee [58] found that the solubility of PCDD/Fs was enhanced by the presence of humic matter. Therefore, the authors concluded that fly ash should not be landfilled with organic wastes in order to prevent leachability of PCDD/Fs [58].

In Europe, some countries have different regulations established for the ash streams that can be applied to soils and different requirements for levels of nutrients and heavy metals allowed, such as the Nord Test Technical Report [59]. POPs are limited in a few countries; in Denmark PAHs control is required only if unburned matter in ashes is higher than $5 \%$ with a limit of $3 \mathrm{mg} / \mathrm{kg}$ for 9 PAHs [59] and in the Czech Republic the limit is $20 \mathrm{mg} / \mathrm{kg}$ [60]. In Sweden there are different limits for carcinogenic and non-carcinogenic PAHs in soils, depending on the soils used sensitivity [61]. In Canada, in addition to the limits for naphthalene and benzo(a)pyrene in wood ashes ( $4.0 \mathrm{mg} / \mathrm{kg}$ for each), PCDD/Fs are also limited to $27 \mathrm{ng}$ TEQ/kg [62]. In Portugal, alternative fertilizers containing sewage sludge and biomass ashes have limits of $6 \mathrm{mg} / \mathrm{kg}$ for PAHs, and $100 \mathrm{ng}$ TEQ/kg for PCDD/Fs [63]. In Germany, the regulation for applying fertilizer restricts PCDD/Fs + PCBs to $8 \mathrm{ng} \mathrm{TEQ} / \mathrm{kg}$ for pasture lands, and $30 \mathrm{ng} \mathrm{TEQ} / \mathrm{kg}$ for agricultural soils [17]. In Europe, the recent harmonization of EU fertilizers aims at valorizing some wastes as Component Material Categories (CMC) for use as alternative fertilizers [64]. Thermal oxidation materials and derivates, namely ash-based materials, are to be included; in addition to the control of heavy metals, the proposed limit for $\Sigma_{16} \mathrm{PAH}$ is $6 \mathrm{mg} / \mathrm{kg}$ and for PCDD/Fs is $20 \mathrm{ng}$ TEQ/kg, respectively [65]. TEQ are the Toxic Equivalents corresponding to the revised $\mathrm{WHO}_{2005}$ TEQ [66].

Aware of the perilous nature of ashes, frequently obliviated in many studies concerning ash applications as fertilizers, it is important to initiate further practical investigations to determine the PCDD/Fs and PAHs contents and define if the ashes can be used as fertilizers or need a safe disposal. The purpose of this work is to investigate the presence of PCDD/Fs and PAHs in industrial biomass ashes, to distinguish the degree of contamination of different ash streams and evaluate if they comply with the upcoming European Regulation for use of ashes as fertilizers. Also, we wanted to understand the source of POPs in ashes, namely relating with the composition and contamination of the fired biomasses and constitution of ashes. Furthermore, we conducted a literature survey to provide a 
deeper assessment of the fate of PCDD/Fs and PAHs in biomass combustion and compile up-to-date regulations and programs within the subject. In the experimental part we present chemical data of the residual forest biomass used in four biomass power stations and of various biomass ash streams collected over a year. The distribution of the 17 toxic PCDD/Fs and 16 PAHs measured in biomass and in ash blends is interpreted in view of their constitution. The potential toxicity of ashes is evaluated by calculating TEQs and BaP-EQs, according to various protocols. Also, a sensitivity analysis was performed to understand the impact of management of non-detected (ND) congeners on aggregate quantities used in policy regulation, such as TEQs, $\Sigma \mathrm{PCDD} / \mathrm{Fs}$ and $\Sigma \mathrm{PAHs}$. The ND handling can be critical for environmental risk assessment and evaluation of compliance with limit values.

\section{Literature Review}

\subsection{PCDD/Fs and TEQs; PAHs and BaP Equivalents}

Of the 210 PCDD/Fs congeners (75 PCDDs and 135 PCDFs), only 10 PCDFs and 7 PCDDs containing 2,3,7,8-Cl substitutions, have been appointed for environmental risk assessment given their high Aromatic Hydrocarbon Receptor (AhR) bioactivity (Table 1) [67]. The toxicity of a complex mixture of PCDD/Fs is usually expressed as Toxic Equivalent (TEQ). TEQ consists of an aggregate measure obtained with the sum of the individual congener concentrations multiplied by their specific Toxic Equivalent Factor (TEF). TEFs correlate each congener's toxicity potency to the most toxic 2,3,7,8-TCDD [18,68].

Table 1. List of 17 polychlorinated dibenzo-p-dioxins and polychlorinated dibenzofurans (PCDD/Fs) congeners and Toxic Equivalent Factors (TEFs) for Toxic Equivalents (TEQ) calculations.

\begin{tabular}{|c|c|c|c|c|}
\hline & PCDD/Fs Congeners & I-TEF [68] & $\mathrm{WHO}_{1998}-\mathrm{TEF}^{\mathrm{a}}$ [69] & $\mathrm{WHO}_{2005}-\mathrm{TEF}^{\mathrm{a}}[65]$ \\
\hline \multirow{10}{*}{ 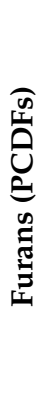 } & $2,3,7,8-\mathrm{TCDF}$ & 0.1 & 0.1 & 0.1 \\
\hline & $1,2,3,7,8-\mathrm{PeCDF}$ & 0.05 & 0.05 & $0.03^{b}$ \\
\hline & $2,3,4,7,8-\mathrm{PeCDF}$ & 0.5 & 0.5 & 0.3 \\
\hline & $1,2,3,4,7,8-\mathrm{HxCDF}$ & 0.1 & 0.1 & 0.1 \\
\hline & $1,2,3,6,7,8-\mathrm{HxCDF}$ & 0.1 & 0.1 & 0.1 \\
\hline & $2,3,4,6,7,8-\mathrm{HxCDF}$ & 0.1 & 0.1 & 0.1 \\
\hline & $1,2,3,7,8,9-\mathrm{HxCDF}$ & 0.1 & 0.1 & 0.1 \\
\hline & $1,2,3,4,6,7,8-\mathrm{HpCDF}$ & 0.01 & 0.01 & 0.01 \\
\hline & $1,2,3,4,7,8,9-\mathrm{HpCDF}$ & 0.01 & 0.01 & 0.01 \\
\hline & OCDF & 0.001 & 0.0001 & 0.0003 \\
\hline \multirow{7}{*}{ 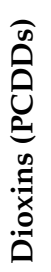 } & $2,3,7,8-\mathrm{TCDD}$ & 1 & 1 & 1 \\
\hline & $1,2,3,7,8-\mathrm{PeCDD}$ & 0.5 & 1 & 1 \\
\hline & $1,2,3,4,7,8-\mathrm{HxCDD}$ & 0.1 & 0.1 & 0.1 \\
\hline & $1,2,3,6,7,8-\mathrm{HxCDD}$ & 0.1 & 0.1 & 0.1 \\
\hline & $1,2,3,7,8,9-\mathrm{HxCDD}$ & 0.1 & 0.1 & 0.1 \\
\hline & $1,2,3,4,6,7,8-\mathrm{HpCDD}$ & 0.01 & 0.01 & 0.01 \\
\hline & OCDD & 0.001 & 0.0001 & 0.0003 \\
\hline
\end{tabular}

Notes: ${ }^{\mathrm{a}}$ dl-PCBs not mentioned in the table. ${ }^{\mathrm{b}}$ Changed values in bold.

The TEF concept was introduced in 1977 and was adopted internationally, in 1988, as I-TEQ for the 17 PCDD/Fs [69]. The World Health Organization and International Program on Chemical Safety (WHO/IPCS) continually reevaluates the TEF system and later on included the dioxin-like toxicity PCBs (dl-PCB) (12 non-ortho/mono-ortho-substituted polychlorinated biphenyls) in the TEQ protocol, $\mathrm{WHO}_{1998}$-TEQ [70]. In the latest revision, $\mathrm{WHO}_{2005}$ TEQ [66], modified some TEF values, as shown in Table 1. The possible inclusion of other compounds with dioxin-like effects, such as brominated and mixed halogenated dioxins/furans, is currently under evaluation [66].

Unequivocally, the oldest publications use I-TEQ and subsequently $\mathrm{WHO}_{1998}$-TEQ (including or not dl-PCBs), however, they are still in use [10]. Kato and Urano [71] found good correlations between 
different TEQ protocols for stack emissions of various incineration facilities, since minor modifications were made in the toxic factors (Table 1 ).

$$
\begin{gathered}
\left(\mathrm{WHO}_{1998}-\mathrm{TEQ}(\mathrm{PCDD} / \mathrm{F})\right)=1.14 \times(\mathrm{I}-\mathrm{TEQ}) \\
\left(\mathrm{WHO}_{1998}-\mathrm{TEQ}(\mathrm{PCDD} / \mathrm{F} / \mathrm{dl}-\mathrm{PCB})\right)=1.17 \times(\mathrm{I}-\mathrm{TEQ})
\end{gathered}
$$

For wood boilers, the $\mathrm{WHO}_{1998}$-TEQ values were reported to be $10-25 \%$ higher than I-TEQ, depending on the congener distribution profile, which is within the measurement uncertainty [72]. From results of Moltó team, two correlations are extracted; Equation (3) [73] and Equation (4) [74].

$$
\begin{aligned}
& \left(\mathrm{WHO}_{2005}-\mathrm{TEQ}(\mathrm{PCDD} / \mathrm{F})\right)=0.88 \times(\mathrm{I}-\mathrm{TEQ}) \\
& \left(\mathrm{WHO}_{2005}-\mathrm{TEQ}(\mathrm{PCDD} / \mathrm{F})\right)=0.99 \times(\mathrm{I}-\mathrm{TEQ})
\end{aligned}
$$

Differences in the correlations may be attributed to the variation of congeners distribution and concentration, given the different magnitude of TEFs.

When reporting WHO-TEQs, reference to the inclusion of dl-PCBs should be made [75]. Nevertheless, the share of dl-PCBs in the $\mathrm{WHO}_{1998}-\mathrm{TEQ}(\mathrm{PCDD} / \mathrm{F} / \mathrm{dl}-\mathrm{PCB})$ emissions from waste incineration plants was found to be less than 3\% [71], and less than $16 \%$ for different industrial sources [76]. For biomass combustion emissions, the share of dl-PCBs on $\mathrm{WHO}_{2005}-\mathrm{TEQ}(\mathrm{PCDD} / \mathrm{F} / \mathrm{dl}-$ PCB) was found to vary from $0.7-22 \%$ [73], and 5.8-23\% [74]. In municipal solid wastes incineration (MSWI) fly ashes, the contribution of dl-PCBs to $\mathrm{WHO}_{2005}$-TEQ(PCDD/F/dl-PCB) was less than 5\% [77]. The share of dl-PCBs on TEQs was found to increase along the flue gas paths equipped with APCDs. This is mainly due to the different adsorptions of PCDD/Fs and dl-PCBs on fly ashes that affect their partition between particle and gas phase [78]. The different volatilities of compounds may also influence the relative proportions of compounds along the exit flue gas path. In another matrix, such as soils and fertilizers, the relevance of dl-PCBs may however be quite different [79].

Also important for TEQ calculation is the strategy to account non-quantified or non-detected (ND) values of individual PCDD/F congeners, as different methodologies can be applied [80-82]. The simplest approach consists of the imputation method; attribution of fractions of the Estimated Quantification Level (EQL) for each congener: the Upper Bound (UB) with ND = EQL, the Medium Bound $(\mathrm{MB})$ with $\mathrm{ND}=\mathrm{EQL} / 2$, and the Lower Bound (LB) with $\mathrm{ND}=0$. Different options might lead to different TEQ values, which can hamper accurate risk assessment and evaluation of compliance with regulations [83]. Delistraty and Singleton [84] also evaluated the influence of TEQ schemes and ND handling on TEQs of wood ashes. They verified that the impact of ND handling on TEQs increased with the number of non-detected congeners in wood ash. It was also shown that the ND options had higher influence than the TEQ scheme, for the lower concentrations of PCDD/Fs. Hence, accuracy of small concentrations is of prime importance, even for the evaluation of ash application in soils, for example, use of wood ashes with 1.4-840 ng TEQ/kg was estimated to increase soil's PCDD/F concentrations by $0.038-23 \mathrm{ng} \mathrm{TEQ} / \mathrm{kg}$ a year [84].

EU regulations on the measurement of PCDD/Fs and PCBs in feed [85] and foodstuff [86] specifies that analytical reports must contain the levels of individual congeners measured, the TEQ values must be reported as LB, MB and UB and differences between LB and UB must be lower than $20 \%$. Different approaches are in use, while the NCASI report [87] computes TEQ for wood boilers emissions assuming ND as zero, other studies $[75,88,89]$ use the MB option. In the previous paper [56], the TEQ results presented were those provided by the analytical laboratory, which assumed the UB option. Reporting the ND handling and quantification/detection levels is frequently absent in the literature, which misleads the interpretation of results. Given the complexity of PCDD/Fs analysis, analytical sensibility may vary widely, depending on the sample characteristics and performance/focus of the laboratory (e.g., food control, environmental or waste analysis) [90]. The BAT/BEP guidelines [11] 
also mention that the reporting of PCDD/Fs and dl-PCBs should use LB and UB approaches for ND, and the required quantification levels should be a least $1 / 5$ of the regulatory limits or levels of interest.

PAHs are ubiquitous pollutants, comprising hundreds of lipophilic compounds with fused aromatic rings. They may have natural or anthropogenic origin, existing in many commonly used goods [91]. The United States Environmental Protection Agency (US-EPA) listed 16 PAHs compounds as priority pollutants for environmental risk assessment due to their toxic effects [92]. Table 2 presents the US-EPA 16 PAHs list and the acronyms used in this work. PAHs can be divided in two classes: Low Molecular Weight PAHs (LPAHs) with two and three benzenoid rings (Nap, Acy, Ace, FL, Phe and Ant), and High Molecular Weight PAHs (HPAHs) with four or more benzenoid rings (Flut, Pyr, BaA, Chry, BbFA, BkFA, BaP, DahA, BghiP and IP).

Table 2. List of Polycyclic Aromatic Hydrocarbons (PAHs), Carcinogenicity Classification and Toxicity Factors for BaP-EQ calculations.

\begin{tabular}{|c|c|c|c|c|c|c|}
\hline & PAHs Compounds & Acronym & Number Rings & $\begin{array}{c}\text { IARC }^{\mathbf{a}} \\
{[96]}\end{array}$ & $\begin{array}{c}\text { RPF } \\
\text { US-EPA } \\
\text { [101] }\end{array}$ & $\begin{array}{c}\text { RPF } \\
\text { N\&L } \\
{[98]} \\
\end{array}$ \\
\hline \multirow{6}{*}{ 芠 } & Naphthalene & $\mathrm{NaP}$ & 2 & $2 \mathrm{~B}$ & - & 0.001 \\
\hline & Acenaphthylene & Acy & 3 & - & - & 0.001 \\
\hline & Acenaphthene & Ace & 3 & 3 & - & 0.001 \\
\hline & Fluorene & FL & 3 & 3 & - & 0.001 \\
\hline & Phenanthrene & Phe & 3 & 3 & - & 0.001 \\
\hline & Anthracene & Ant & 3 & 3 & - & 0.01 \\
\hline \multirow{10}{*}{ 趇 } & Fluoranthene & Flut & 4 & 3 & - & 0.001 \\
\hline & Pyrene & Pyr & 4 & 3 & - & 0.001 \\
\hline & Benzo[a]anthracene & $\mathrm{BaA}$ & 4 & $2 \mathrm{~B}$ & 0.1 & 0.1 \\
\hline & Chrysene & Chry & 4 & $2 \mathrm{~B}$ & $0.001^{c}$ & 0.01 \\
\hline & Benzo[b]fluoranthene ${ }^{b}$ & $\mathrm{BbFA}$ & 5 & $2 \mathrm{~B}$ & 0.1 & 0.1 \\
\hline & Benzo[k]fluoranthene ${ }^{b}$ & BkFA & 5 & $2 \mathrm{~B}$ & 0.01 & 0.1 \\
\hline & Benzo[a]pyrene ${ }^{b}$ & $\mathrm{BaP}$ & 5 & 1 & 1 & 1 \\
\hline & Dibenzo[a,h]anthracene & DahA & 5 & $2 \mathrm{~A}$ & 1 & 5 \\
\hline & Benzo[g,h,i]perylene & BghiP & 6 & 3 & - & 0.01 \\
\hline & Indeno $[1,2,3-c, d]$ pyrene ${ }^{b}$ & IP & 6 & $2 \mathrm{~B}$ & 0.1 & 0.1 \\
\hline
\end{tabular}

Notes: a IARC classification: 1-Carcinogenic, 2 A-Probably carcinogenic, 2 B-Possibly carcinogenic, 3- Not classifiable as carcinogenicity. ${ }^{\mathrm{b}}$ PAHs used by Persistent Organic Pollutants (POPs) Protocol. ${ }^{\mathrm{c}}$ Different values in bold.

LPAHs such as NaP, are usually present in larger quantities in the air phase, and considered acutely toxic to aquatic organisms since they are more water-soluble than HPAHs [93]. Other organizations selected diverse PAHs compounds, and still no worldwide consensus exists. The POPs Protocol [4] uses four PAHs (BaP, BbFA, BkFA and IP) for emissions inventory. In the EU [94], also 16 PAHs are contemplated, although less may be considered. The Directive 2004 on air quality [95] includes BaP, $\mathrm{BaA}, \mathrm{BbFA}, \mathrm{BjFA}, \mathrm{BkFa}$, DahA and IP. Only eight PAHs match the EU and US-EPA PAHs list; BaP, BaA, Chry, BbFA, BkFA, DahA, BghiP and IP. Excluding BghiP, the other PAHs in common are classified as carcinogenic, both by International Agency for Research on Cancer (IARC) [96] and US EPA [97] (Table 2). IARC classifies PAHs in different categories, according to carcinogenic potency (Table 2); $\mathrm{BaP}$ is classified in group 1- Carcinogenic to humans, and the others are $2 \mathrm{~A}$ and $2 \mathrm{~B}$. NaP is classified as carcinogenic by IARC, but usually is not considered for risk assessment. Flut has been suspected to be carcinogenic, although not confirmed by IARC [94].

Since the eighties, correlations of PAHs toxicities with the most toxic BaP have been pursued [94,98-100]. The equivalence factors of Nisbet and Lagoy (N\&L) [98] have been broadly used. US-EPA proposes similar Relative Potency Factors (RPF) (Table 2) [101]. While US-EPA considers DahA as carcinogenic as BaP, Nisbet and Lagoy attributed a factor of five to DahA, for its carcinogenicity proved to be higher than $\mathrm{BaP}$ in low doses. Jung et al. [102] used the factor of five for DahA for assessment of the urban air toxicity exposures of young children. Other equivalence systems are used worldwide, as those used by Ramirez et al. [103]. Owing to the PAHs complex toxicity mechanisms, 
and assorted PAHs lists, the BaP toxic equivalence system is yet far from general consensus [99,100]. Since this equivalence system is not compatible with the TEQ protocol of PCDD/Fs and dl-PCBs, to discern them, the PAHs factors are herein called RPF and not TEF, and BaP-EQ should be used instead of TEQ-BaP. BaP alone is frequently used as a surrogate for PAHs control [95] and, in fact, there are correlations found between BaP and $\Sigma$ PAHs produced in wood combustion $[104,105]$.

\subsection{Origin, Generation and Fate of PCDD/Fs and PAHs in Combustion Processes}

Several tragic historical events like the Agent Orange in Vietnam and Seveso accident [106-108], and more recently animal feed contamination with biodiesel sub-products [109], brought the PCDD/Fs issue to worldwide research focus, regulation, and continuous surveillance. The formation of PCDD/Fs in the combustion process was firstly reported in 1977 for waste incineration systems [110]. Since then, PCDD/Fs have been broadly investigated, despite the complexity and high costs associated with their characterization.

Pre-existing PCDD/Fs in materials used as fuels, such as PCDD/F contaminated PCP treated wood, may be a source of emissions, for complete destruction is achieved only in high efficient combustion systems, with long residence times, typically above $1000^{\circ} \mathrm{C}$, and dedicated flue gas treatment.

In combustion processes, however, PCDDs and PCDFs can also be formed through two pathways: primary formation by the precursor's mechanism, and secondary formation by de novo synthesis. The two mechanisms operate simultaneously and independently, in different zones of the combustion systems, and depend on various parameters like fuel composition (mainly $\mathrm{Cl}, \mathrm{Cu}$ and $\mathrm{S}$ ) and presence of organic contaminants, furnace conditions and flue gas treatment applied [111-117]. In the hottest furnace zones $\left(>650^{\circ} \mathrm{C}\right)$ and low $\mathrm{O}_{2}, \mathrm{PCDD} / \mathrm{Fs}$ originate from precursors like lignin of biomass, waste wood preservative additives containing pentachlorophenol (PCP), PCBs, and other compounds, such as chlorobenzenes, chlorophenols and PAHs, which may be also formed during poor combustion $[115,118]$. In the post combustion zones, like ESP and baghouse filters, de novo synthesis involves catalyzed chlorination of carbonaceous structures present in fly ashes, between $250-500{ }^{\circ} \mathrm{C}$ or higher, with a peak at $300{ }^{\circ} \mathrm{C}$, Cu being the more relevant catalyzer [111,119-123]. Studies on combustion of salty laden wood revealed that $99 \%$ of total PCDD/Fs were associated to cyclone and ESP fly ashes, and their main formation was suggested to be de novo synthesis over fly ashes [124]. Tests performed between $260-430{ }^{\circ} \mathrm{C}$, revealed that $\mathrm{PCDD} / \mathrm{Fs}$ formation decreases for lower temperatures and shorter residence times $[125,126]$. Accordingly, the operation of ESP at low temperatures, preferably at $140-200{ }^{\circ} \mathrm{C}$, is a key procedure to reduce $\mathrm{PCDD} / \mathrm{Fs}$ formation by de novo synthesis, allowing simultaneously adsorption on fly ash to decrease emissions with flue gases [124,127-129].

Efforts have been dedicated to characterizing PCDD/Fs fingerprints, and to find congener's surrogate for TEQ estimation, which could allow faster and cheaper diagnostics of emission sources [130]. In combustion systems, PCDFs/PCDDs ratios (F/D) larger than one are interpreted as a preponderance of de novo synthesis that yields more PCDFs, while the precursor mechanism is believed to generate PCDDs preferentially $[129,131,132]$. F/D ratios have also been correlated with $\mathrm{Cl}$ availability; low concentrations appear to be mostly used for chlorination of phenols, forming preferentially PCDDs at high temperatures. High $\mathrm{Cl}$ in fuels is often associated with the worst combustion conditions, producing more PICs that are further cracked and chlorinated to form PCDFs in the post-combustion zones [133]. Therefore, the F/D ratio increases for higher $\mathrm{Cl}$ contents. Amounts of $\mathrm{Cu}$ in fuels also increase F/D ratios, due to higher PCDFs formation in the post-combustion zones [134]. On the other hand, the presence of moisture in the gas phase has been found to increase PCDDs formation over PCDFs, at low temperatures [135].

All PCDD/Fs congeners can be found in solid discharges from incinerators [136-139], in increasing concentrations from the furnace bottom to the flue gas exit (bottom-ash $<$ boiler-ash $<$ ESPash $<$ filter-cake-ash < fly-dust); PCDD/Fs contents in wood fly ashes were reported to be 10 times higher than in corresponding bottom ashes [140]. The PCDDs concentrations generally increase with the 
increasing degree of chlorination $(\mathrm{nCl})$ of the congeners; OCDD is usually present in higher amounts, followed by 1,2,3,4,6,7,8-HpCDD. A more random distribution occurs for PCDFs; the hepta, hexa and penta PCDFs, being more prevalent than OCDF [35,124,129,131,141-148]. Moreover, in MSWI bottom ashes lower PCDD/Fs concentrations were found in larger particles $[149,150]$, which suggest that ash separation may provide less contaminated fractions.

$\mathrm{Cl}$ is the limiting reactant for PCDD/Fs formation; however, the relation between PCDD/Fs yields and $\mathrm{Cl}$ amounts (and its speciation) is not completely understood [124,151,152]. Variations within low $\mathrm{Cl}$ contents appear to make little difference, while high concentrations strongly increase PCDD/Fs $[87,153,154]$. During combustion, $\mathrm{Cl}$ is released from the inorganic or organic matrix, generating predominantly $\mathrm{HCl}$, although metal chlorides might also form. $\mathrm{HCl}$ can be converted to gaseous $\mathrm{Cl}_{2}$ through the catalyzed Deacon reaction, which is maximized at about $300{ }^{\circ} \mathrm{C}$, in the presence of $\mathrm{O}_{2}$ and $\mathrm{Cu}$. $\mathrm{Cl}_{2}$ is believed to be more active as a chlorinating agent than $\mathrm{HCl}$, owing to the faster production of highly reactive $\mathrm{Cl}$ radicals [121,155-158]. Simultaneously, metal chlorides eventually present in fly ashes, such as $\mathrm{CuCl}_{2}$, might behave as $\mathrm{Cl}$ donors, chlorinating the carbon structures directly, in the presence of $\mathrm{O}_{2}[118,119,151]$. Moreover, the chlorination of dibenzofuran (DF) has been found to be favored over chlorination of dibenzo-p-dioxin (DD), corroborating that higher $\mathrm{Cl}$ correlates with higher F/D ratios in waste incinerators [159].

Woody biomass with low $\mathrm{Cl}$ contents usually produces low PCDD/Fs, while co-combustion with streams containing $\mathrm{Cl}$ and metals (salty wood biomass, bleached kraft mill waste water sludges, straw and cereal residues, treated wood with PCP base preservatives or other metal base preservatives, sewage sludge, etc.), enhances PCDD/F production [27,72,124,143,146,152,160,161]. In the past, biomass co-combustion with paper bleaching sludge generated cyclone fly ashes with PCDD/Fs concentrations attaining $210 \mathrm{ng}$ TEQ/kg [162]. Tame et al. [115] verified that the firing of waste wood, impregnated with $\mathrm{Cu}$ base preservatives, increased the basal PCDD/Fs levels of clean wood ash by two to three orders of magnitude and the F/D increased because of preferential formation of PCDFs. Oehme and Muller [140] also revealed that TEQs in filter ash from waste wood incineration may be three orders of magnitude higher $(100-10,000 \mathrm{ng} T E Q / \mathrm{kg})$ than for clean wood combustion. Studies performed in waste wood chips incinerators in Taiwan have shown that PCDD/Fs in baghouse fly ashes were extremely high; $38,060 \mathrm{ng}$ I-TEQ/ $/ \mathrm{kg}$ in the boiler operating at $850-925^{\circ} \mathrm{C}$ and $98,570 \mathrm{ng}$ $\mathrm{I}-\mathrm{TEQ} / \mathrm{kg}$ in the boiler operating at lower temperatures, $500-850^{\circ} \mathrm{C}$ [146].

Duo et al. [163] reported that combustion of salt-laden wood with $0.1-2 \% \mathrm{NaCl}$, in coastal boilers, resulted in PCDD/Fs emissions two to three orders of magnitude higher than those burning wood with lower $\mathrm{Cl}$. More research in coastal boilers, burning salty wood, revealed that the decrease of PCDD/Fs concentrations in ESP fly ashes was influenced not only by the decrease of $\mathrm{Cl}$ concentrations, but was also due to working at lower furnace loads, $65 \%$, that might have promoted better combustion [152]. Someshwar [27] verified that the PCDD/F contents in ESP fly ashes were higher in European boilers, burning forest biomass, than in similar USA boilers, possibly due to higher $\mathrm{Cl}$ levels present in the European forest biomass harvest near the Ocean's coasts.

Sulphur has been broadly described as decreasing $\mathrm{Cl}$ activity to produce PCDD/Fs $[27,72,152,155,158,164-173]$. At high $S$ concentrations $(\mathrm{S} / \mathrm{Cl}>10)$, in the presence of $\mathrm{H}_{2} \mathrm{O}$, inhibition of de novo synthesis is due to $\mathrm{SO}_{2}$ oxidation to $\mathrm{SO}_{3}$ reverting $\mathrm{Cl}_{2}$ to $\mathrm{HCl}$ [174]. The same effect was found for lower S/Cl; below 2.5 [175], and also below 0.64 [166]. Another inhibition mechanism consists in the poisoning of $\mathrm{Cu}$ catalyst by formation of $\mathrm{CuSO}_{4}$ (stable until about $\left.80{ }^{\circ} \mathrm{C}\right)[158,165,166,176-178]$. Gullet et al. [177] pointed out that the higher stability of $\mathrm{CuSO}_{4}$ favors its retention in furnace bottom zones; thus, lower $\mathrm{Cu}$ contents in fly ash are available for de novo synthesis. They also suggested that sulfonation of the phenolic precursors prevents their conversion to PCDD/Fs. Therefore, the presence of $S$ may affect the F/D ratios, given the lower formation of PCDFs [172]. Thomas and McCreight [176] proposed a positive correlation of PCDD/Fs emissions on Cl and $\mathrm{Cu}$, and inverse on $\mathrm{S}$ for several fuels. Since natural biomass usually contains low $\mathrm{S}$ concentrations, the increase of $\mathrm{S}$ may be achieved by co-combustion with other fuels containing higher $\mathrm{S}$ or use of 
S-base additives. Other chemical inhibitors may be used $[120,155,179,180]$, such as the addition of N-S containing compounds, for example, $\left(\mathrm{NH}_{4}\right)_{2} \mathrm{SO}_{4}$ (ChlorOut technique) and urea [171,181-186].

Similarly, to $\mathrm{Cu}$, other metals present in fuels, namely $\mathrm{Fe}, \mathrm{Ni}, \mathrm{Cr}, \mathrm{Zn}, \mathrm{Pb}$ and $\mathrm{Al}$, catalyze PCDD/Fs formation, chlorination and dechlorination [116,120,122,156,187-191]. For metal chlorides Zhang et al. [189] consider two functions; as catalysts and as $\mathrm{Cl}$ donors, $\mathrm{CuCl}_{2}$ being the most active, followed by $\mathrm{CrCl}_{3}, \mathrm{NiCl}_{2}$, and $\mathrm{ZnCl}_{2}$. Addink and Altwicker [192] verified that $\mathrm{CuCl}$ and $\mathrm{CuCl}_{2}$ were better as $\mathrm{Cl}$ donors than as catalyzers, at $353{ }^{\circ} \mathrm{C}$, in the presence of $\mathrm{O}_{2}$. Meanwhile, earth alkaline metals, $\mathrm{Ca}$ and $\mathrm{Mg}$, have shown a depressor effect on PCDD/Fs formation [116,193]. $\mathrm{CaSO}_{4}$ is formed in the bottom zones of $\mathrm{FB}$ systems, consuming $\mathrm{SO}_{3}$, which converts $\mathrm{Cl}_{2}$ back to $\mathrm{HCl}$. Ca may also capture $\mathrm{HCl}$ forming liquid $\mathrm{CaCl}_{2}$ in the $\mathrm{FB}$ bottom zones [169], and/or absorb $\mathrm{HCl}$ in the post-combustion zones, preventing formation of $\mathrm{Cl}_{2}$ [194]. This effect was found to be maximized at $350{ }^{\circ} \mathrm{C}$ [195] and $310^{\circ} \mathrm{C}$ [196]. Moreover, $\mathrm{NaOH}$ and $\mathrm{KOH}$ have shown similar effects [197]. However, ashes are mainly composed by aluminas and aluminosilicates, which may serve as active catalytic surfaces for PCDD/Fs formation in the post-flame zones [198].

PCDD/Fs congeners, and other PICs, results from balances of formation, destruction, and dechlorination/hydrogenation [116,132,145,199-206]. Weber and co-workers [207,208] observed increasing dechlorination of OCDD and OCDF, from 260 to $380{ }^{\circ} \mathrm{C}$, under poor $\mathrm{O}_{2}$. At lower temperatures, the catalytic dechlorination by $\mathrm{Cu}$ was more efficient than with other metals, while $\mathrm{Ca}$ seemed to preferentially promote destruction. It was also verified a preferential dechlorination in the 1,4,6-positions than in the 2,3,7,8-positions. Thus, elimination of the most toxic PCDD/Fs was not effective at low temperatures. Vogg et al. [120] verified that formation of PCDD/Fs in ESP fly ashes, annealed at $300^{\circ} \mathrm{C}$, substantially increased with $\mathrm{O}_{2}$ availability. However, in the presence of moisture, the $\mathrm{nCl}$ degree of PCDDs decreased from 6.85 to 5.65, and $\mathrm{nCl}$ of PCDFs decreased from 5.21 to 4.96, which was attributed to dechlorination. Stieglitz et al. [135] confirmed the influence of water vapor on dechlorination and observed a decrease of F/D ratios. Experiments of the Hagenmaier group $[188,209]$ have shown that, even at temperatures as low as $120^{\circ} \mathrm{C}$, in the presence of $\mathrm{H}_{2} \mathrm{O}$ vapor and absence of $\mathrm{O}_{2}$, dechlorination and decomposition of PCDD/Fs occur very rapidly. Yasuhara et al. [210] found out that metals present in waste paper combustion decreased PCDD/Fs emissions in the order of $\mathrm{Cu}>\mathrm{Mg}>\mathrm{Mn}>\mathrm{Fe}>\mathrm{Ni}>\mathrm{Co}$, probably involving dechlorination and oxidation. Hasselriis [127] also revealed that $\mathrm{Cu}$ catalyze the dechlorination of PCDD/Fs between $150-280{ }^{\circ} \mathrm{C}$, in the presence of $\mathrm{O}_{2}$, forming the more toxic penta and hexa PCDDs and PCDFs from the octa forms. Modeling of PCDD/Fs formation [211], under low $\mathrm{O}_{2}$ atmospheres, showed that the dechlorination takes place in the presence of $\mathrm{CaO}$ and $\mathrm{Na}$-silicates as $\mathrm{Cl}$ scavengers. The calculated Gibbs energy for dechlorination of various congeners, using different oxides and silicates, led to conclude that the dechlorination of OCDF and OCDD is thermodynamically favored than that of TCDF and TCDD.

Chen et al. [212] evaluated combustion of wood chips from furniture shredding, with $\mathrm{Cl}$ below $0.001 \%$, but containing $8.4 \mathrm{ng} / \mathrm{kg}$ PCDD/Fs; more than $80 \%$ were OCDD $+1,2,3,4,6,7,8-\mathrm{HpCDD}$ and $\mathrm{F} / \mathrm{D}=0.15$. About $80 \%$ of the total PCDD/Fs output remained in various ash streams, and $20 \%$ was emitted with the flue gases. The output/input ratio of the grate furnace revealed that half of the PCDD/Fs mass entered with the biomass was destroyed in the furnace. However, the I-TEQ output/input was 6.9 because more of the lower chlorinated PCDD/Fs were formed. The F/D ratio increased from 0.14 in biomass to 1.5 in ashes, indicating possible formation of low chlorinated PCDFs. There was also an increase of low chlorinated PCDDs, attributed to formation by precursor mechanism or dechlorination of OCDD and HpCDD contained in the wood chips. lino et al. [200] suggested that dechlorination might be even more important for OCDF than for PCDDs. Wehrmeier et al. [213] also highlighted the importance of hydrodechlorination reactions of OCDD in fly ash $\left(\right.$ at $\left.350{ }^{\circ} \mathrm{C}\right)$, in producing varied congeners, including the $2,3,7,8 \mathrm{TCDD}$ and others substituted in non 2,3,7,8 positions. In fact, ashes may contain many of the $210 \mathrm{PCDD} / \mathrm{Fs}$, as well as various PICs and products of dechlorination involved in PCDD/Fs chemistry, such as DD, DF and PAHs [201,214]. A deeper understanding of mechanisms 
involved in PCDD/Fs formation requires a more exhaustive analysis than the target list compounds normally used for risk assessment [215].

PAHs compounds are formed by complex mechanisms involving cyclization and aromatization of carbonaceous matter in the pyrolysis phase of combustion process, at temperatures typically higher than $400{ }^{\circ} \mathrm{C}$, with optimum temperature in the $700-900^{\circ} \mathrm{C}$ range [216-218]. The thermal destruction of PAHs requires higher temperatures and oxidant conditions $[219,220]$. Therefore, the yield of PAHs depends on fuel composition and contamination, combustion conditions (temperature, oxygen, residence time and turbulence) and also flue gas treatment $[34,50]$. Fuel contaminants, such as creosote (a wood preservative), can be important sources of PAHs in combustion systems [61]. PAHs formed in biomass combustion appear to be mostly associated with gas emissions and soot deposits; while LPAHs (two to three rings) are preferentially present in gas phase emissions, HPAHs (more than three rings) are more associated with ashes [33,221,222]. Johansson and Bavel [61] detected PAHs contents as high as $77 \mathrm{mg} / \mathrm{kg}$, of which $11 \mathrm{mg} / \mathrm{kg}$ were carcinogenic, in ashes from a biomass boiler. Masto et al. [50] found $0.18-2.61 \mathrm{mg} / \mathrm{kg}$ of PAHs in bottom ashes, and 3.59-193 mg/kg in fly ashes from combustion of several biomass residues. LPAHs were preponderant, with $\mathrm{NaP}$ accounting for $50-90 \%$ in fly ashes, while in bottom ashes more of the three, four and five rings were detected. BaP and other carcinogenic PAHs were found below $0.51 \mathrm{mg} / \mathrm{kg}$ in both ashes. Straka and Havelcová [53] detected $6.16 \mathrm{mg} / \mathrm{kg}$ of PAHs in a biomass ash containing unburned matter (14.5\%), and thus suggested the need to measure PAHs in ashes for soil application, when unburned matter exceeds 9\%. However, high PAHs, including the carcinogenic ones, were found in porous fly ash particles from rice husk combustion, independently of their unburned content [223]. Sarenbo [51] detected high contents of PAHs, $91-300 \mathrm{mg} / \mathrm{kg}$, in biomass fly ashes of winter seasons, containing $25-45 \%$ unburned carbon. NaP was prevalent (44-120 mg/kg), followed by Acy, Phe, Pyr and Flut, and the carcinogenic IP and BaP reached 7.7 and $3.9 \mathrm{mg} / \mathrm{kg}$, respectively. Rey-Salgueiro et al. [49] found relatively low levels of PAHs in biomass ashes, although $0.4 \mathrm{mg} / \mathrm{kg}$ were present in bottom ashes containing $26 \%$ organic matter. Correlation of PAHs contents in ash with their unburned carbon content are commonly referred [26]. Košnář et al. [60] found exponential correlations of PAHs with unburned matter (loss in ignition-LOI) for wood fly ashes containing 3.8-148 mg/kg of PAHs. However, the levels of LOI were unusually high, reaching $55 \%$.

Benfenati et al. [224] showed straight correlations between PAHs, PCNs and PCDD/Fs contents in waste incineration, suggesting formation by common reactions. Schoonenboom and Olie [225] showed that PCDDs and PCDFs may be generated from anthracene and 2-chloroanthracene, at $250-300{ }^{\circ} \mathrm{C}$, in the presence of $\mathrm{KCl}$ and $\mathrm{CuCl}_{2}$, over alumina. Moreover, Iino et al. [226] revealed that some PAHs compounds produce $\mathrm{PCDFs}$ and $\mathrm{PCNs}$, at $200-400{ }^{\circ} \mathrm{C}$, in the presence of $\mathrm{O}_{2}$. Also, it was demonstrated that PCDD/Fs with a high F/D ratio can be produced by heating various PAHs at $300{ }^{\circ} \mathrm{C}$, with $\mathrm{CuCl}_{2}$ as a catalyst; perylene being the most efficient [227]. Weber et al. [228] suggested that the different patterns of PCDF isomers observed for stoker furnaces and fluidized bed systems could be attributed to their formation from PAHs with perylene structures. Wilhelm et al. [229] also found that some PAHs usually present in fly ash; fluorene, fluoranthene, phenanthrene and anthracene, originate PCDD/Fs at $250^{\circ} \mathrm{C}$, preferentially PCDFs.

To effectively decrease yields of PCDD/Fs in biomass boilers, in addition to optimization of combustion conditions and use of adequate flue gas treatment, the composition of fuels is of prime interest. Besides controlling contents of metals and $\mathrm{Cl}$ (and other halogens), the pre-existence of PCDD/Fs in fuels must be avoided, as well as the absence of chemicals used as wood preservatives, pesticides and fertilizers that may serve as PCDD/Fs precursors. Hence, inclusion of treated waste wood and other wastes in biomass boilers should be avoided to prevent formation of very toxic unintentional POPs, such as PCDD/Ds, PCBs and carcinogenic PAHs. 


\section{Experimental Part}

\subsection{Materials and Methods}

Experiments were performed within the scope of a project dedicated to the study of biomass ash quality in view of its application in soils. Four boilers of biomass power stations located in Portugal, near the Atlantic coast, were involved. Three boilers consist of Bubbling Fluidized Bed systems (BFB) located in pulp \& paper plants. They consume mainly forest biomass residues (FBR), composed of shredded bark and branches of eucalyptus trees used for pulp making and paper sludge (from primary and secondary wastewater treatment). Variable quantities of other forest residues are used, such as pine remains and weed trees. Some of these boilers are allowed to consume till $10 \%$ of MSW and other non-contaminated biomass residues. The fourth boiler is a grate furnace (GF) also consuming FBR, pine and eucalyptus residues from wildfires and plague control, and occasionally agricultural residues from olive oil production or wood industries. All boilers are equipped with ESPs to reduce particulate emissions. The study was developed during 2011-2013 under the normal and steady operation of boilers.

Sampling campaigns lasted a year, during which four or five biomass composed samples were collected, by increments, in the conveyer belts of the furnace's feeding systems of each boiler. In total, 18 biomass samples were prepared for individual chemical analysis; the extraneous mineral matter (rocks, sand, and loosely attached soil) was previously separated by sieving below $2 \mathrm{~mm}$ and manual separation. The samples were dried and milled below $0.63 \mathrm{~mm}$ and the analyses were performed according to ASTM, EPA, ISO and CEN/TS standards for biomass analysis or equivalent methods in LNEG installations, as described previously [230].

For PCDD/Fs analyses, representative biomass blends of each boiler, containing the individual samples collected for one year, were prepared. Also, sludge from pulp \& paper wastewater treatment (mix of 70\% primary and 30\% secondary sludge) was analyzed for chemical composition and PCDD/Fs. A soil sample collected in the experimental forest campus, used in the project to test ash fertilization, was also tested for PCDD/Fs.

Ash samples were collected in the four boilers: monthly in BFB1 and BFB3 $(n=12)$, bimonthly in GF $(n=6)$ and three times a year in BFB4 $(n=4)$. The nature of ash streams collected varies depending on the furnace assembling, ash removal systems installed and ash management strategy. In each boiler, the ash flows are combined in two streams; bottom ash (BA) and fly ash (FA), as described in Table 3. In unit BFB4, BA includes bottom bed ashes and ashes from the economizer (EC), superheater (SH), thus, FABFB4 corresponds only to fly ash from the ESP. For the other three units, BA corresponds only to bottom or grate ashes, therefore, FA are mixes of EC, SH, and ESP ashes.

In total, 60 ash samples (30 BA and $30 \mathrm{FA}$ ) were prepared for individually chemical analysis. The extraneous matter, above $2 \mathrm{~mm}$, was sieved out. Samples were analyzed following adequate ASTM, EPA, ISO and CEN/TS standards or equivalent methods in LNEG, as described previously $[56,230]$. For each boiler, representative ash blends (4 BA and $4 \mathrm{FA}$ ) containing the ashes collected during a year were prepared for PCDD/Fs and PAHs analysis. The bulk chemical analysis, leachability, TEQs and $\Sigma$ PAHs of some of these ash blends were previously presented [56] but additional and more detailed results are provided herein.

The PCDD/Fs and PAHs analysis were subcontracted to the Portuguese Reference Laboratory of Agência Portuguesa do Ambiente (APA). PAHs were analyzed using an APA internal method (MMA 98 - SPE-SOX, HPLC/DAD-FLD), based on US EPA method 550.1. PCDD/Fs were analyzed using an APA internal method (MMA 123-LLE-SOX, HRGC/HRMS), based on US EPA method 1613. 
Table 3. Identification of biomass ash streams.

\begin{tabular}{cccc}
\hline & Ash Stream & Combustion Technology & Ash Flows Included \\
\hline & BABFB1 & BFB & Bottom bed \\
BABFB3 & BFB & Bottom bed \\
& BABFB4 & BFB & Bottom bed + EC + SH \\
BAGF & GF & Grate ash \\
& FABFB1 & BFB ash ESP + EC + SH \\
& FABFB3 & BFB & Fly ash ESP + EC + SH \\
& FABFB4 & BFB & Fly ash ESP \\
\hline
\end{tabular}

Notes: BFB—Bubbling Fluidized Bed, GF-GrateFurnace, SH—Superheater, EC-Economizer, ESP—Electrostatic Precipitator.

The lists of $17 \mathrm{PCDD} / \mathrm{Fs}$ and $16 \mathrm{PAHs}$ analyzed correspond to those normally used for environmental risk assessment, as presented in Tables 1 and 2. For calculation of TEQs of PCDD/Fs, several protocols were used, as described previously; I-TEQ, $\mathrm{WHO}_{1998}$-TEQ and $\mathrm{WHO}_{2005}$-TEQ, using TEFs mentioned in Table 1. For PAHs, BaP-EQs were calculated using the equivalence factors of Nisbet and Lagoy [98] and US-EPA [101], presented in Table 2.

Also, a sensitivity analysis was applied in the calculation of $\Sigma$ PCDD/Fs, $\Sigma$ PAHs, TEQs and BaP-EQs, using the imputation approach to non-detect (ND) values, based on the estimated quantification levels (EQLs) reported by the analytical laboratory: Low Bound (LB) with $\mathrm{ND}=0$, Medium Bound (MB) with $\mathrm{ND}=\mathrm{EQL} / 2$ and Upper Bound (UB) with $\mathrm{ND}=\mathrm{EQL}$.

\subsection{Results and Discussion}

\subsubsection{Chemical Composition and PCDD/F in Biomass, Sludge and Soil}

Table 4 presents the ranges of mineral composition of the individual biomass samples collected in each boiler, plus the sludge mix.

The composition of biomass samples is typical of woody biomass [231]. The wide ranges of ash concentrations and major ash forming elements, like $\mathrm{Si}$ and $\mathrm{Ca}$, may be due to seasonal fluctuations, mainly because of higher soil adhesion to biomass in the raining seasons. Since the extraneous mineral fractions of biomass were excluded from analysis, higher quantities of these materials can be found in produced ashes than the analysis would lead on. The results obtained suggest that co-combustion of sludge might also increase ash production in the boilers, given their high contents of ash forming elements, such as $\mathrm{Ca}(23 \%)$. In addition, the sand used as a fluidizing bed agent in BFB systems also contributes to ash amounts. Scatter of other elements concentrations may reflect natural biologic cycles, although interpretation of variations can be misled due to dilution effects of major elements. In addition to $\mathrm{Si}(0.169-2.44 \%)$, Ca is the main ash-forming element of biomasses $(0.21-1.83 \%)$, followed by $\mathrm{K}, \mathrm{Na}$, $\mathrm{Al}, \mathrm{Fe}, \mathrm{Mg}$ and $\mathrm{P}$. Of the heavy metals measured, $\mathrm{Mn}$ is preponderant, as usually found in woody biomass [231]. $\mathrm{Cu}, \mathrm{Ni}, \mathrm{Cr}, \mathrm{Pb}, \mathrm{Zn}$ and $\mathrm{Cd}$ are found in trace levels, below $140 \mathrm{mg} / \mathrm{kg}$, and $\mathrm{Hg}$ does not exceed $0.05 \mathrm{mg} / \mathrm{kg}$. One biomass sample collected in BFB3 is responsible for the extreme values of $\mathrm{Cu}$, $\mathrm{Zn}, \mathrm{Pb}$, and $\mathrm{Cd}$ levels (Table 4). Concentrations of S (0.01-0.16\%) are low, as for similar biomass [231]. However, the $\mathrm{Cl}$ contents show a wider range, $0.04-0.28 \%$ (77\% of which are above $0.15 \%$ ) which is above the common $\mathrm{Cl}$ levels found in woody biomass (0.01-0.05\%) [231]. The higher concentrations of $\mathrm{Cl}$ might be explained in light of the constitution of the residual forest biomass consumed in the studied boilers; mainly eucalyptus barks from pulp \& paper industries. Wood barks originated from trees harvested in oceanic's coasts regions are usually more contaminated with dust deposits and salty mist coming from the sea, mainly containing $\mathrm{NaCl}$ [27]. Indeed, the overview of biomass constitution of Vassilev et al. [231] refers to a eucalyptus bark having $0.26 \%$ of $\mathrm{Cl}$. Other works [152,163] report the same issue, and established correlations between $\mathrm{Cl}$ and PCDD/Fs formation in wood boilers. Many of the $\mathrm{Cl}$ contents of the residual forest biomass samples approach the guide limit, $\mathrm{Cl}<0.3 \%$, advised to minimize PCDD/Fs formation during combustion of cereal residues [232]. As aforementioned, high $\mathrm{S} / \mathrm{Cl}$ ratios are important for inhibiting $\mathrm{PCDD} / \mathrm{F}$ formation. For the biomass samples analyzed, 
except one case (1.3), the $\mathrm{S} / \mathrm{Cl}$ ratios (0.02-1) were possibly too low for effective PCDD/Fs inhibition. Co-combustion of sludge similar to the one analyzed could increase $S$ in the system, however given its high $\mathrm{Cl}$ content, the $\mathrm{S} / \mathrm{Cl}$ would not be significantly improved.

Table 4. Chemical composition of biomass (min-max) and sludge, in dry base.

\begin{tabular}{|c|c|c|c|c|c|}
\hline & $\begin{array}{l}\text { Sludge Mix } \\
\left(1^{\circ} / 2^{\circ}-70 / 30\right)\end{array}$ & $\begin{array}{c}\text { Biomass BFB1 } \\
\quad(n=5)\end{array}$ & $\begin{array}{c}\text { Biomass BFB3 } \\
\quad(n=5)\end{array}$ & $\begin{array}{c}\text { Biomass BFB4 } \\
\quad(n=4)\end{array}$ & $\begin{array}{c}\text { Biomass GF } \\
\quad(n=4)\end{array}$ \\
\hline Ash\% & 74 & $2.4-8.3$ & $1.5-6.5$ & $4.2-10.6$ & $4.3-6.7$ \\
\hline $\mathrm{N} \%$ & 1.29 & $0.22-0.35$ & $0.32-0.71$ & $0.26-0.43$ & $0.22-0.32$ \\
\hline $\mathrm{S} \%$ & 0.31 & $0.01-0.08$ & $0.02-0.07$ & $0.03-0.16$ & $0.02-0.03$ \\
\hline $\mathrm{S} \%$, avg & - & 0.04 & 0.05 & 0.08 & 0.03 \\
\hline $\mathrm{Cl}^{\%}$ & 0.60 & $0.08-0.28$ & $0.04-0.19$ & $0.10-0.12$ & $0.15-0.24$ \\
\hline $\mathrm{Cl} \%$, avg & - & 0.22 & 0.13 & 0.11 & 0.19 \\
\hline $\mathrm{Cu} \mathrm{mg/kg}$ & 12 & $3-5$ & $3-55$ & $6-11$ & $6-9$ \\
\hline $\mathrm{Ni} \mathrm{mg} / \mathrm{kg}$ & 17 & $2-9$ & $1-16$ & $17-36$ & $2-32$ \\
\hline $\mathrm{Cr} \mathrm{mg} / \mathrm{kg}$ & 9 & $9-17$ & $2-22$ & $28-58$ & $21-60$ \\
\hline $\mathrm{Zn} \mathrm{mg/kg}$ & 25 & $7-11$ & 10-139 & $17-37$ & $11-24$ \\
\hline $\mathrm{Pb} \mathrm{mg} / \mathrm{kg}$ & 12 & $1-3$ & 1-34 & $2-6$ & $2-5$ \\
\hline $\mathrm{Cd} \mathrm{mg/kg}$ & $<3$ & $<0.2$ & $<0.2-0.3$ & $<0.3$ & $<0.3$ \\
\hline $\mathrm{Hg} \mathrm{mg} / \mathrm{kg}$ & 0.061 & $0.007-0.021$ & $0.012-0.030$ & $0.012-0.026$ & $0.015-0.047$ \\
\hline $\mathrm{Mn} \mathrm{mg/kg}$ & 512 & $172-434$ & 70-232 & 145-321 & $361-802$ \\
\hline $\mathrm{Fe} \%$ & 0.18 & $0.04-0.14$ & $0.03-0.33$ & $0.08-0.32$ & $0.10-0.31$ \\
\hline $\mathrm{Al} \%$ & 0.49 & $0.07-0.36$ & $0.07-0.33$ & $0.15-0.70$ & $0.20-0.53$ \\
\hline $\mathrm{Ca} \%$ & 23.2 & $0.34-1.83$ & $0.21-0.98$ & $0.72-1.56$ & $0.58-0.82$ \\
\hline $\mathrm{Na} \%$ & 0.61 & $0.05-0.21$ & $0.03-0.14$ & $0.04-0.08$ & $0.07-0.12$ \\
\hline $\mathrm{K} \%$ & 0.50 & $0.17-0.39$ & $0.11-0.34$ & $0.28-0.47$ & $0.40-0.66$ \\
\hline $\mathrm{Mg} \%$ & 0.39 & $0.06-0.20$ & $0.05-0.12$ & $0.12-0.16$ & $0.10-0.20$ \\
\hline $\mathrm{P} \%$ & 0.35 & $0.03-0.07$ & $0.02-0.47$ & $0.08-0.18$ & $0.09-0.13$ \\
\hline $\mathrm{Si} \%$ & 1.6 & $0.16-1.56$ & $0.17-1.07$ & $0.59-2.44$ & $0.53-1.54$ \\
\hline $\mathrm{S} / \mathrm{Cl}$ ratio & 0.5 & $0.02-1.0$ & $0.3-0.6$ & $0.2-1.3$ & $0.1-0.2$ \\
\hline $\mathrm{S} / \mathrm{Cl}$ ratio, avg & - & 0.29 & 0.4 & 0.7 & 0.1 \\
\hline
\end{tabular}

Notes: $\mathrm{n}$-number of individual samples analyzed, avg—average.

Table 5 presents the contents of PCDD/Fs of three biomass blends from BFB3, BFB4 and GF, plus the sludge mix and the soil sample tested. PCDD/Fs congeners are not detected in this sludge. The soil contains $43 \mathrm{ng} / \mathrm{kg}$ of OCDD, which is comparable to other forest soils in Germany [233]. Other congeners might be present, though in lower concentrations than the EQLs reported. In the biomass blends, only OCDD was detected, below $260 \mathrm{ng} / \mathrm{kg}$, except in the case of BFB3 that also contains 1,2,3,4,6,7,8-HpCDD above the detection limit. Interestingly, this biomass blend includes the biomass sample showing the extreme concentrations of heavy metals (Table 4). The PCDD/Fs concentrations found in biomasses are consistent with levels found in natural sinks, for example, $5.4-330 \mathrm{ng} / \mathrm{kg}$ in pine needles from rural to higher industrialized areas [234].

Combustion/incineration systems are among the possible emission sources of PCDD/Fs found in soils and vegetation; however, they emit a broad range of PCDD/Fs congeners (preferentially PCDFs) which does not match the environmental profiles enriched in OCDD. Baker and Hites [235] realized that PCDD/Fs sources/deposition mass balances were inconsistent because of excessive OCDD and hepta-PCDD deposition. The excessive OCDD inventory was explained in light of the historical worldwide use of huge quantities of wood preservatives/fungicides containing PCP. In fact, OCDD was a contaminant of PCP preservatives fabrication, thus, it contributed directly to environmental PCDD/Fs sinks, namely soils and vegetation, essentially nearby production plants and application of PCP in agriculture. In addition, deposited PCP volatilizes forming OCDD in the atmosphere water droplets under UV light, spreading contamination all over the world. Notwithstanding PCP pesticide discontinuation, the legacy to the environment contamination is enormous. Still, great concerns on the use of chemicals in soils prevail, since by 2006 , about 161 other pesticides were suspected to contain 
PCDD/Fs [236]. Cammenzuli et al. [237] evidenced that OCDD contamination of agricultural soils in Australia is mainly due to the former use of pesticides, in particular $\mathrm{PCP}$, and that resuspension to air and periodic burning of agricultural wastes contribute to disperse OCDD over non-agricultural fields. Additionally, PCDD/Fs may originate by photolytic formation from other precursors like chlorophenols, polychlorinated phenoxyphenols and polychlorinated diphenylethers with origin in pesticides production or their progressive degradation, as well as other chemicals such as the widely used biocide triclosan [238]. Forest fires, which are suspected to produce PCDD/Fs [160], also appear to have mainly a dispersive effect of OCDD and precursors existing in vegetation and soils [239]. Predominance of OCDD in the environment may also be enhanced by aging due to preferential degradation of the lower chlorinated PCDD/Fs by natural UV photolysis [240-242].

Table 5. PCDD/Fs and TEQs of biomass blends, sludge and soil, in dry base.

\begin{tabular}{|c|c|c|c|c|c|}
\hline (ng/kg) & $\begin{array}{c}\text { Sludge Mix } \\
\left(1^{\circ} / 2^{\circ}=70 / 30\right)\end{array}$ & Soil & $\begin{array}{c}\text { Biomass Blend } \\
\text { BFB3 }\end{array}$ & $\begin{array}{c}\text { Biomass Blend } \\
\text { BFB4 }\end{array}$ & $\begin{array}{c}\text { Biomass Blend } \\
\text { GF }\end{array}$ \\
\hline 2,3,7,8-TCDF & $\mathrm{ND}(2.0)^{1}$ & $\mathrm{ND}(2.0)$ & $\mathrm{ND}(2.0)$ & $\mathrm{ND}(2.0)$ & $\mathrm{ND}(2.0)$ \\
\hline $1,2,3,7,8-\mathrm{PeCDF}$ & $\mathrm{ND}(12)$ & $\mathrm{ND}(12)$ & $\mathrm{ND}(12)$ & $\mathrm{ND}(12)$ & $\mathrm{ND}(12)$ \\
\hline 2,3,4,7,8-PeCDF & $\mathrm{ND}(12)$ & $\mathrm{ND}(12)$ & ND(12) & $\mathrm{ND}(12)$ & $\mathrm{ND}(12)$ \\
\hline $1,2,3,4,7,8-\mathrm{HxCDF}$ & $\mathrm{ND}(12)$ & $\mathrm{ND}(12)$ & $\mathrm{ND}(12)$ & $\mathrm{ND}(12)$ & $\mathrm{ND}(12)$ \\
\hline $1,2,3,6,7,8-\mathrm{HxCDF}$ & $\mathrm{ND}(12)$ & $\mathrm{ND}(12)$ & $\mathrm{ND}(12)$ & $\mathrm{ND}(12)$ & $\mathrm{ND}(12)$ \\
\hline $2,3,4,6,7,8-\mathrm{HxCDF}$ & $\mathrm{ND}(12)$ & $\mathrm{ND}(12)$ & $\mathrm{ND}(12)$ & $\mathrm{ND}(12)$ & $\mathrm{ND}(12)$ \\
\hline 1,2,3,7,8,9-HxCDF & $\mathrm{ND}(12)$ & $\mathrm{ND}(12)$ & $\mathrm{ND}(12)$ & $\mathrm{ND}(12)$ & $\mathrm{ND}(12)$ \\
\hline $1,2,3,4,6,7,8-\mathrm{HpCDF}$ & $\mathrm{ND}(12)$ & $\mathrm{ND}(12)$ & $\mathrm{ND}(12)$ & $\mathrm{ND}(12)$ & $\mathrm{ND}(12)$ \\
\hline $1,2,3,4,7,8,9-\mathrm{HpCDF}$ & $\mathrm{ND}(12)$ & $\mathrm{ND}(12)$ & $\mathrm{ND}(12)$ & $\mathrm{ND}(12)$ & $\mathrm{ND}(12)$ \\
\hline OCDF & $\mathrm{ND}(24)$ & $\mathrm{ND}(24)$ & $\mathrm{ND}(24)$ & $\mathrm{ND}(24)$ & $\mathrm{ND}(24)$ \\
\hline 2,3,7,8-TCDD & $\mathrm{ND}(2.0)$ & $\mathrm{ND}(2.0)$ & $\mathrm{ND}(2.0)$ & $\mathrm{ND}(2.0)$ & $\mathrm{ND}(2.0)$ \\
\hline 1,2,3,7,8-PeCDD & $\mathrm{ND}(12)$ & $\mathrm{ND}(12)$ & $\mathrm{ND}(12)$ & $\mathrm{ND}(12)$ & $\mathrm{ND}(12)$ \\
\hline $1,2,3,4,7,8-\mathrm{HxCDD}$ & $\mathrm{ND}(12)$ & $\mathrm{ND}(12)$ & $\mathrm{ND}(12)$ & $\mathrm{ND}(12)$ & $\mathrm{ND}(12)$ \\
\hline 1,2,3,6,7,8-HxCDD & $\mathrm{ND}(12)$ & $\mathrm{ND}(12)$ & $\mathrm{ND}(12)$ & $\mathrm{ND}(12)$ & $\mathrm{ND}(12)$ \\
\hline 1,2,3,7,8,9-HxCDD & $\mathrm{ND}(12)$ & $\mathrm{ND}(12)$ & $\mathrm{ND}(12)$ & $\mathrm{ND}(12)$ & $\mathrm{ND}(12)$ \\
\hline $1,2,3,4,6,7,8-\mathrm{HpCDD}$ & $\mathrm{ND}(12)$ & $\mathrm{ND}(12)$ & 35 & $\mathrm{ND}(12)$ & $\mathrm{ND}(12)$ \\
\hline OCDD & $\mathrm{ND}(25)$ & 43 & 260 & 67 & 29 \\
\hline$\Sigma \mathrm{PCDD} / \mathrm{F} \mathrm{MB}^{2}$ & 105 & 135 & 382 & 160 & 122 \\
\hline $\mathrm{LB} / \mathrm{UB}^{2}$ & $0 / 210$ & $43 / 228$ & $295 / 468$ & $67 / 252$ & $29 / 214$ \\
\hline I-TEQ MB & 11.8 & 11.8 & 12.3 & 11.9 & 11.8 \\
\hline $\mathrm{WHO}_{1998}$-TEQ MB & 14.8 & 14.8 & 15.1 & 14.8 & 14.8 \\
\hline $\mathrm{WHO}_{2005}$-TEQ MB & 13.5 & 13.5 & 13.8 & 13.5 & 13.5 \\
\hline LB/UB & $0 / 26.9$ & $0.01 / 26.9$ & $0.43 / 27.2$ & $0.02 / 26.9$ & $0.009 / 26.9$ \\
\hline
\end{tabular}

Notes: ${ }^{1}$ ND-non-detected, (EQL)—Estimated Quantification Level, ${ }^{2}$ LB-Lower-Bound $(\mathrm{ND}=0$ ), MB-Medium-Bound (ND = EQL/2), UB-Upper Bound (ND = EQL).

The calculated $\Sigma \mathrm{PCDD} / \mathrm{Fs}$ and TEQs using UB, MD and LB approaches for ND, are presented in Table 5. The differences between LB and UB reveal how discrepant the reported $\Sigma$ PCDD/Fs and TEQs can be, for each sample, depending on the ND attribution option. The quantification levels (EQLs), i.e., the sensitivity of the analytical methodology, have a great influence on $\Sigma \mathrm{PCDD} / \mathrm{Fs}$ and TEQs. The sludge is an extreme case of this influence; $\Sigma$ PCDD/Fs may be assumed as 0 , or 105, or $210 \mathrm{ng} / \mathrm{kg}$, and TEQ as 0 , or 13.5 , or $26.9 \mathrm{ng} \mathrm{WHO}_{2005}-\mathrm{TEQ} / \mathrm{kg}$, depending on the ND option. Independently of samples having detectable congeners or ND for all, TEQ values using the MB option are similar for the various samples, $14 \mathrm{ng} \mathrm{WHO}_{2005}-\mathrm{TEQ} / \mathrm{kg}, 15 \mathrm{ng} \mathrm{WHO} 1998-\mathrm{TEQ} / \mathrm{kg}$ and $12 \mathrm{ng} \mathrm{I}-\mathrm{TEQ} / \mathrm{kg}$. Using the UB option, TEQs are also identical among samples. For the LB option, TEQs of biomass blends vary from 0.009-0.43 ng $\mathrm{WHO}_{2005}-\mathrm{TEQ} / \mathrm{kg}$. Similar TEQs were obtained by Moltó et al. [74] in pine needles and cones, 0.66 and $0.33 \mathrm{ng} \mathrm{I}-\mathrm{TEQ} / \mathrm{kg}$, with preponderance of OCDD, followed by 1,2,3,4,6,7,8-HpCDD and $1,2,3,4,6,7,8-\mathrm{HpCDF}$, and some other congeners, generally in low quantities.

The TEQs calculated with different protocols are very similar; $\mathrm{WHO}_{2005}$-TEQs are about $10 \%$ higher than I-TEQs, and about $10 \%$ lower than the $\mathrm{WHO}_{1998}$-TEQs, in accordance with van den Berg et al. [66]. 


\subsubsection{Chemical Composition, PCDD/Fs and PAHs in Ashes}

Table 6 presents the ranges of mineral composition of the individual ash samples collected in each boiler.

Table 6. Chemical composition of biomass ash samples (min-max), in dry base.

\begin{tabular}{|c|c|c|c|c|c|c|c|c|}
\hline & \multicolumn{2}{|c|}{ BFB1 } & \multicolumn{2}{|c|}{ BFB3 } & \multicolumn{2}{|c|}{ BFB4 } & \multicolumn{2}{|c|}{ GF } \\
\hline & $\begin{array}{c}\text { BA } \\
(n=12)\end{array}$ & $\begin{array}{c}\text { FA } \\
(n=12)\end{array}$ & $\begin{array}{c}\text { BA } \\
(n=12)\end{array}$ & $\begin{array}{c}\text { FA } \\
(n=12)\end{array}$ & $\begin{array}{c}\text { BA } \\
(n=4)\end{array}$ & $\begin{array}{c}\text { FA } \\
(n=4)\end{array}$ & $\begin{array}{c}\text { BA } \\
(n=6)\end{array}$ & $\begin{array}{c}\text { FA } \\
(n=6)\end{array}$ \\
\hline $\mathrm{C} \%$ & $0.1-0.5$ & $1.4-5.6$ & $<0.1-0.4$ & $0.9-1.7$ & $0.1-0.3$ & $1.2-3.8$ & $0.7-4.2$ & $5.1-12$ \\
\hline $\mathrm{S} \%$ & $0.01-0.07$ & $0.3-1.4$ & $<0.01-0.01$ & 1 $0.2-1.3$ & $<0.01$ & $0.2-1.2$ & $<0.01$ & $0.1-0.8$ \\
\hline $\mathrm{Cl} \%$ & $0.01-0.22$ & $1.3-8.1$ & $0.004-0.02$ & $0.14-2.2$ & $0.006-0.03$ & $0.31-0.66$ & $0.007-0.01$ & $0.23-1.4$ \\
\hline $\mathrm{Cu} \mathrm{mg} / \mathrm{kg}$ & $13-36$ & $35-90$ & $19-51$ & $49-85$ & $<10-575$ & $30-167$ & $33-43$ & $38-92$ \\
\hline $\mathrm{Ni} \mathrm{mg} / \mathrm{kg}$ & $<10$ & $24-65$ & $<10$ & $16-83$ & $<10$ & $13-21$ & $11-21$ & $14-28$ \\
\hline $\mathrm{Cr} \mathrm{mg} / \mathrm{kg}$ & $11-30$ & $33-95$ & $11-21$ & $40-125$ & $<10-24$ & $38-70$ & $47-73$ & $41-60$ \\
\hline $\mathrm{Zn} \mathrm{mg/kg}$ & 25-194 & $22-249$ & $28-186$ & $159-357$ & $32-244$ & $82-358$ & $27-45$ & $115-765$ \\
\hline $\mathrm{Pb} \mathrm{mg} / \mathrm{kg}$ & $<10-12$ & $22-135$ & $<10-23$ & $39-173$ & $<10-58$ & $31-133$ & $<10$ & $14-75$ \\
\hline $\mathrm{Cd} \mathrm{mg/kg}$ & $<4$ & $<4$ & $<4$ & $<4$ & $<4$ & $<4-5$ & $<4$ & $<4$ \\
\hline $\mathrm{Hg} \mathrm{mg} / \mathrm{kg}$ & $<0.001$ & $0.01-0.22$ & $<0.002$ & $0.10-0.31$ & $<0.001$ & $0.08-0.16$ & $<0.005$ & $0.05-0.52$ \\
\hline $\mathrm{Mn} \mathrm{mg} / \mathrm{kg}$ & $581-1160$ & $2671-6482$ & $125-830$ & $914-3282$ & $229-433$ & $1016-1526$ & $1452-2094$ & $1648-4264$ \\
\hline $\mathrm{Fe} \%$ & $0.4-1.6$ & $0.9-3.5$ & $0.4-1.1$ & $1.6-3.9$ & $0.4-0.7$ & $1.3-1.7$ & $2.6-4.6$ & $2.3-4.1$ \\
\hline $\mathrm{Al} \%$ & $0.6-3.3$ & $1.9-6.6$ & $0.7-2.7$ & $3.5-8.2$ & $1.8-2.3$ & $3.8-6.0$ & $5.6-8.1$ & $5.1-8.5$ \\
\hline $\mathrm{Ca} \%$ & $1.5-5.7$ & $8.2-31$ & $0.8-4.8$ & $3.0-15$ & $0.5-3.2$ & $3.9-17$ & $3.4-6.7$ & $3.0-8.2$ \\
\hline $\mathrm{Na} \%$ & $0.2-2.7$ & $0.8-2.3$ & $0.1-0.6$ & $0.6-1.6$ & $0.1-0.3$ & $0.6-1.2$ & $0.5-0.8$ & $0.6-0.9$ \\
\hline $\mathrm{K} \%$ & $0.5-2.8$ & $3.9-7.5$ & $0.5-2.2$ & $2.5-4.5$ & $1.6-1.9$ & $3.4-3.7$ & $3.0-3.5$ & $3.1-4.8$ \\
\hline $\mathrm{Mg} \%$ & $0.2-2.5$ & $1.3-2.8$ & $0.1-0.5$ & $0.7-1.6$ & $0.1-0.2$ & $0.7-1.1$ & $0.8-1.2$ & $0.9-1.6$ \\
\hline P\% & $0.1-0.3$ & $0.3-0.7$ & $0.02-0.1$ & $0.3-1.1$ & $0.04-0.1$ & $0.4-3.8$ & $0.2-0.3$ & $0.3-0.5$ \\
\hline $\mathrm{Si} \%$ & $33-40$ & $7.5-23$ & $32-37$ & $16-27$ & $39-40$ & $21-29$ & $25-30$ & $19-25$ \\
\hline
\end{tabular}

Notes: $n —$ number of individual samples analyzed, BA—bottom ash (Table 3), FA—fly ash (Table 3).

Ashes contain mainly $\mathrm{Si}$, variable quantities of $\mathrm{Ca}, \mathrm{K}, \mathrm{Fe}, \mathrm{Al}, \mathrm{Mg}, \mathrm{Na}, \mathrm{Ti}, \mathrm{P}, \mathrm{Cl}$ and $\mathrm{S}$, and trace quantities of heavy metals. Except Si, most inorganic elements are in higher quantities in FA than BA. Due to the use of sand in BFB systems, $\mathrm{Si}$ is higher in all BABFB than in BAGF, while concentrations are more similar in BAGF and FAGF. In BFB, the C contents are generally lower in FA than BA [26]. The GF ashes contain much higher $C$ contents, revealing serious efficiency problems of the boiler. This GF boiler was retrofitted afterward. Ashes of BFB1 show some extreme values of $\mathrm{Cl}, \mathrm{Ca}, \mathrm{Na}$ and $\mathrm{Mg}$, which may be correlated with their higher contents in the biomass consumed in that boiler, or/and eventual co-combustion of sludge (Table 4). Cl retention in solid phases may persist until about $800^{\circ} \mathrm{C}$, depending mainly on the presence of $\mathrm{S}, \mathrm{Ca}$, and alkaline metals, and also on combustion conditions $[243,244]$. As BFB boilers operate within $750-850{ }^{\circ} \mathrm{C}$ [230], there may be instability of $\mathrm{Cl}$ retention by $\mathrm{Ca}$ in the furnace core, releasing some $\mathrm{Cl}$ that may contribute to the generation of PCDD/Fs.

As can be observed in Table 7, PCDD/Fs levels are higher in FA than in BA, except in the case of BFB1. Interpretation of results might be hampered due to the different composition of streams (Table 3), and the presence of several ND congeners. The F/D ratios of FA varies from 0.17-1.1; PCDDs account for $41-86 \%$ of $\Sigma$ PCDD/Fs, which means there is no prevalence of PCDFs, contrary to what is reported for other combustion systems [128,129]. The analyzed ashes contain mostly OCDD and 1,2,3,4,6,7,8-HpCDD, as in other biomass boilers [140], representing 40-70\% of total PCDD/Fs identified. However, also the more toxic 2,3,7,8-PCDD and 1,2,3,7,8-PeCDD were found in all FA. Chlorination degrees $(\mathrm{nCl})$ of PCDD/Fs in FA vary between 6.0-7.3; slightly lower for PCDFs (6.0-6.4) than for PCDDs (7.2-7.3), similarly to other results [129]. These results suggest that perhaps de novo synthesis was not preponderant, although FA contains unburned matter and $\mathrm{Cl}$. The presence of $\mathrm{Ca}$ and alkaline elements might have captured $\mathrm{Cl}$, reducing chlorination to form PCDFs. Also, the low $\mathrm{Cu}$ contents of biomasses may have limited PCDD/Fs formation in the post-combustion zones. However, the 
dechlorination of the original OCDD and HpCDD contained in biomass might have occurred [120,209], giving rise to several congeners, including the more toxic tetra and penta PCDDs.

Table 7. PCDD/Fs and TEQs of biomass ash Blends, in dry base.

\begin{tabular}{|c|c|c|c|c|c|c|c|c|}
\hline \multirow[t]{2}{*}{ ng/kg } & \multicolumn{2}{|c|}{$\begin{array}{c}\text { BFB1 } \\
\text { Ash Blend }\end{array}$} & \multicolumn{2}{|c|}{$\begin{array}{c}\text { BFB3 } \\
\text { Ash Blend }\end{array}$} & \multicolumn{2}{|c|}{$\begin{array}{c}\text { BFB4 } \\
\text { Ash Blend }\end{array}$} & \multicolumn{2}{|c|}{$\begin{array}{c}\text { GF } \\
\text { Ash Blend }\end{array}$} \\
\hline & BA & FA & BA & FA & BA & FA & BA & FA \\
\hline $2,3,7,8-\mathrm{TCDF}$ & $\begin{array}{c}\mathrm{ND}(2.0) \\
1\end{array}$ & 30 & $\mathrm{ND}(2.0)$ & 121 & $\mathrm{ND}(2.0)$ & 88 & $\mathrm{ND}(2.0)$ & 447 \\
\hline 1,2,3,7,8-PeCDF & $\mathrm{ND}(12)$ & 14 & $\mathrm{ND}(12)$ & 43 & $\mathrm{ND}(12)$ & 93 & $\mathrm{ND}(12)$ & 386 \\
\hline $2,3,4,7,8-\mathrm{PeCDF}$ & $\mathrm{ND}(12)$ & 19 & $\mathrm{ND}(12)$ & 49 & $\mathrm{ND}(12)$ & 191 & $\mathrm{ND}(12)$ & 620 \\
\hline $1,2,3,4,7,8-\mathrm{HxCDF}$ & ND(12) & $\mathrm{ND}(12)$ & $\mathrm{ND}(12)$ & 23 & $\mathrm{ND}(12)$ & 111 & $\mathrm{ND}(12)$ & 386 \\
\hline $1,2,3,6,7,8-\mathrm{HxCDF}$ & $\mathrm{ND}(12)$ & $\mathrm{ND}(12)$ & $\mathrm{ND}(12)$ & 26 & $\mathrm{ND}(12)$ & 131 & $\mathrm{ND}(12)$ & 468 \\
\hline $2,3,4,6,7,8-\mathrm{HxCDF}$ & $\mathrm{ND}(12)$ & $\mathrm{ND}(12)$ & $\mathrm{ND}(12)$ & 27 & $\mathrm{ND}(12)$ & 202 & $\mathrm{ND}(12)$ & 640 \\
\hline 1,2,3,7,8,9-HxCDF & $\mathrm{ND}(12)$ & $\mathrm{ND}(12)$ & $\mathrm{ND}(12)$ & $\mathrm{ND}(12)$ & $\mathrm{ND}(12)$ & 64 & $\mathrm{ND}(12)$ & 183 \\
\hline $1,2,3,4,6,7,8-\mathrm{HpCDF}$ & 28 & $\mathrm{ND}(12)$ & $\mathrm{ND}(12)$ & 35 & $\mathrm{ND}(12)$ & 333 & $\mathrm{ND}(12)$ & 976 \\
\hline $1,2,3,4,7,8,9-\mathrm{HpCDF}$ & $\mathrm{ND}(12)$ & $\mathrm{ND}(12)$ & $\mathrm{ND}(12)$ & $\mathrm{ND}(12)$ & $\mathrm{ND}(12)$ & 93 & $\mathrm{ND}(12)$ & 244 \\
\hline OCDF & 101 & $\mathrm{ND}(25)$ & $\mathrm{ND}(24)$ & 27 & $\mathrm{ND}(24)$ & 333 & $\mathrm{ND}(24)$ & 366 \\
\hline 2,3,7,8-TCDD & 5.8 & 6.0 & $\mathrm{ND}(2.0)$ & 26 & $\mathrm{ND}(2.0)$ & 11 & $\mathrm{ND}(2.0)$ & 122 \\
\hline 1,2,3,7,8-PeCDD & $\mathrm{ND}(12)$ & $\mathrm{ND}(12)$ & $\mathrm{ND}(12)$ & 18 & $\mathrm{ND}(12)$ & 48 & $\mathrm{ND}(12)$ & 264 \\
\hline $1,2,3,4,7,8-\mathrm{HxCDD}$ & $\mathrm{ND}(12)$ & 17 & $\mathrm{ND}(12)$ & $\mathrm{ND}(12)$ & $\mathrm{ND}(12)$ & 48 & $\mathrm{ND}(12)$ & 366 \\
\hline $1,2,3,6,7,8-\mathrm{HxCDD}$ & $\mathrm{ND}(12)$ & 33 & $\mathrm{ND}(12)$ & 21 & $\mathrm{ND}(12)$ & 83 & $\mathrm{ND}(12)$ & 1220 \\
\hline $1,2,3,7,8,9-\mathrm{HxCDD}$ & $\mathrm{ND}(12)$ & 23 & $\mathrm{ND}(12)$ & 13 & $\mathrm{ND}(12)$ & 45 & $\mathrm{ND}(12)$ & 793 \\
\hline $1,2,3,4,6,7,8-\mathrm{HpCDD}$ & 98 & 315 & $\mathrm{ND}(12)$ & 121 & $\mathrm{ND}(12)$ & 584 & 20 & 9048 \\
\hline OCDD & 523 & 274 & 33 & 161 & $\mathrm{ND}(24)$ & 685 & 121 & 7523 \\
\hline $\begin{array}{c}\Sigma \mathrm{PCDD} / \mathrm{F} \mathrm{MB}^{2} \\
\mathrm{LB} / \mathrm{UB}^{2}\end{array}$ & $\begin{array}{c}823 \\
755 / 890\end{array}$ & $\begin{array}{c}789 \\
733 / 844\end{array}$ & $\begin{array}{c}126 \\
33 / 219\end{array}$ & $\begin{array}{c}731 \\
713 / 749\end{array}$ & $\begin{array}{c}105 \\
0 / 209\end{array}$ & 3141 & $\begin{array}{c}228 \\
141 / 315\end{array}$ & 24052 \\
\hline I-TEQ MB & 18.4 & 35.9 & 11.9 & 88.3 & 11.9 & 224 & 12.2 & 1144 \\
\hline $\mathrm{WHO}_{1998}$-TEQ MB & 20.9 & 38.6 & 14.9 & 97.2 & 14.9 & 247 & 15.1 & 1270 \\
\hline $\mathrm{WHO}_{2005}$-TEQ MB & 19.7 & 34.6 & 13.5 & 86.5 & 13.5 & 207 & 13.8 & 1139 \\
\hline $\mathrm{LB} / \mathrm{UB}$ & $7.3 / 32.1$ & $25.9 / 43.2$ & $0.01 / 27.1$ & $85.2 / 87.8$ & $0 / 27.1$ & same & $0.2 / 27.3$ & same \\
\hline
\end{tabular}

Notes: ${ }^{1}$ ND-non-detected, (EQL)-Estimated Quantification Level ${ }^{2}$ LB-Lower-Bound $(\mathrm{ND}=0)$, MB-Medium-Bound (ND = EQL/2), UB-Upper Bound (ND = EQL). BA-bottom ash (Table 3), FA—fly ash (Table 3).

PCDD/Fs contents of FABFB4 being higher than those of other BFB boilers appears to be consistent with its constitution (only ESP ashes). In the case of FAGF, although it is a mix of ESP+EC ashes, the levels of PCDD/Fs are even higher, which can be related to the higher C (5.1-12\%), possibly enhancing PCDD/Fs formation and/or higher adsorption [128,143]. In the BA blends only OCDD and $\mathrm{H}_{7}$ CDD were detected, with the exception of BABFB1 that also contains 2,3,7,8-TCDD, OCDF and one $\mathrm{H}_{7} \mathrm{CDF}$ isomer. The corresponding FABFB1 contains more congeners, resulting in a higher TEQ than in BABFB1, despite its slightly lower $\Sigma$ PCDD/F. The similar FABFB3 contains even more congeners, including TCDD and $\mathrm{P}_{5} \mathrm{CDD}$, thus, although having similar $\Sigma \mathrm{PCDD} / \mathrm{Fs}$, its TEQ is more than twice that of BABFB1.

Similar to what is observed for biomass and other samples (Table 4), different assumptions for ND have significant impacts on $\Sigma$ PCDD/Fs and TEQs of ashes, as can be seen in Table 7.

Comparing with published results [143], TEQs in the studied BA match those of bottom ash from combustion of native wood, or waste wood, depending on the ND option. As for FA, TEQs obtained are more similar to those of fly ash from residual wood combustion (18-6300 ng I-TEQ/kg), than from native wood (1.5-4.0 ng I-TEQ/kg). The higher TEQ of FAGF also matches the I-TEQ range of fly ash from waste wood combustion (730-21,000 ng I-TEQ/kg). The higher levels of PCDD/Fs in ashes were correlated with poor burnout of ashes, which resembles the case of FAGF. 
In general, results show that $\mathrm{WHO}_{1998}$-TEQs are higher than I-TEQs, and $\mathrm{WHO}_{2005}$-TEQs are lower than $\mathrm{WHO}_{1998}$-TEQs, and also lower than I-TEQs. Taking in account that dl-PCB are not included in the study and considering only FA blends, the correlations obtained are as follows:

$$
\begin{gathered}
\left(\mathrm{WHO}_{1998}-\mathrm{TEQ}(\mathrm{PCDD} / \mathrm{F})\right)=1.11 \times(\mathrm{I}-\mathrm{TEQ}) \\
\left(\mathrm{WHO}_{2005}-\mathrm{TEQ}(\mathrm{PCDD} / \mathrm{F})\right)=0.99 \times(\mathrm{I}-\mathrm{TEQ}) \\
\left(\mathrm{WHO}_{2005}-\mathrm{TEQ}(\mathrm{PCDD} / \mathrm{F})\right)=0.90 \times\left(\mathrm{WHO}_{1998}-\mathrm{TEQ}(\mathrm{PCDD} / \mathrm{F})\right)
\end{gathered}
$$

The correlation (6) of $\mathrm{WHO}_{2005}$-TEQ with I-TEQ is similar to the correlation (4) obtained from Molto et al. [74].

Analogous to the fate of heavy metals that are not destroyed in combustion systems and concentrate/enrich in fly ash [245], pre-existing PCDD/Fs in fuels may also enrich in fly ashes. Only under proper combustion conditions they can be destroyed or removed from flue gases [246]. In addition, they may suffer transformations, like dechlorination of the high chlorinated congeners to the lower substituted and more toxic hexa, penta, and tetra PCDD/Fs. As an example, one can calculate the possible magnification of a pre-existing quantity of PCDD/F in biomass, as follows: considering that $100 \mathrm{ng} / \mathrm{kg}$ of OCDD present in biomass are not destroyed, and that $80 \%$ of the OCDD is transferred to ESP fly ashes [247] (which may represent about $0.5 \%$ of the fuel biomass), the levels of OCDD in ESP fly ashes would reach 16,000 $\mathrm{ng} / \mathrm{kg}$, corresponding to about $5 \mathrm{ng} \mathrm{WHO} 2005-\mathrm{TEQ} / \mathrm{kg}$. However, if some $10 \%$ of this OCDD dechlorinates and forms 1,2,3,7,8-PeCDD or 2,3,7,8-TCDD, the corresponding TEQ could reach $1600 \mathrm{ng} \mathrm{WHO}_{2005}-\mathrm{TEQ} / \mathrm{kg}$ in ash. This shows that even relatively low PCDD/Fs contents present in the forest biomass, or any other fuel, may produce fly ashes with high TEQs. Highly efficient ESP systems may keep PCDD/Fs air emissions below emission limit values (ELVs), however the collected ashes may become contaminated with PCDD/Fs.

Concentrations of PAHs of ash blends of the units BFB1, BFB3 and GF are presented in Table 8. Most PAHs compounds were non-detected (ND) and many are close to EQLs of PAHs. Levels are relatively low, compared with the $16.8 \mathrm{mg} / \mathrm{kg}$ of PAHs found in wood ash tested as soil fertilizer [55]. Individual concentration of PAHs and $\Sigma_{16}$ PAH of all BA are lower than those of FA blends. Only FABFB3, which also contains significant PCDD/Fs, reveals the presence of carcinogenic Cry and also BghiP, in low concentrations. LPAHs constitute $79-100 \%$ of total PAHs detected, of which the most prevalent is NaP, $52-93 \%$ of $\Sigma$ PAHs, except in BABFB3. Flut and Pyr were reported as the two most abundant HPAHs in wood combustion [72], however, they are present only in FA blends, accounting for less than $24 \%$ of $\Sigma \mathrm{PAH}$. Presence of the highly volatile NaP in ashes, similar to other works [61], might be a result of relevant generation, and/or its fate during and after combustion. NaP can be originated by several pathways, including sequential dechlorination/destruction of PCDD/Fs [248]. Presence of PAHs is usually correlated with unburned matter in ashes and PCDD/Fs, however, this trend was not found in this study; FAGF has similar PAH contents as other FA blends that contain much less C. Some PAHs formed might have been converted to PCDD/Fs, especially PCDF, by cracking and chlorination in the post-combustion zones [229].

The BaP-EQs obtained according to the US-EPA RPFs are about a third lower than those using the factors of Nisbet and Lagoy. This is expected, since RFPs do not cover the non-carcinogenic PAHs, and some RFPs are lower than those of Nisbet and Lagoy, namely for BkFA, DahA, and Chry. Differences between LB and UB of $\Sigma_{16}$ PAH are low, indicating that ND handling has low impact for the PAHs results obtained. The same occurs when accounting for carcinogenics, $\Sigma 7 C$ arc., since the concentration of Chry is close to its EQL. 
Table 8. PAHs, BaP-EQs of biomass ash blends, in dry base.

\begin{tabular}{|c|c|c|c|c|c|c|}
\hline \multirow[t]{2}{*}{$\mathrm{mg} / \mathrm{kg}$} & \multicolumn{2}{|c|}{$\begin{array}{c}\text { BFB1 } \\
\text { Ash Blends }\end{array}$} & \multicolumn{2}{|c|}{$\begin{array}{c}\text { BFB3 } \\
\text { Ash Blends }\end{array}$} & \multicolumn{2}{|c|}{$\begin{array}{c}\text { GF } \\
\text { Ash Blends }\end{array}$} \\
\hline & BA & FA & BA & FA & BA & FA \\
\hline $\mathrm{NaP}$ & 0.016 & 1.727 & $\mathrm{ND}(0.005)$ & 0.776 & 0.060 & 2.338 \\
\hline Acy & $\mathrm{ND}(0.005)^{1}$ & 0.075 & 0.008 & 0.100 & $\mathrm{ND}(0.005)$ & 0.066 \\
\hline Ace & $\mathrm{ND}(0.005)$ & 0.006 & $\mathrm{ND}(0.005)$ & 0.006 & 0.006 & $\mathrm{ND}(0.005)$ \\
\hline FL & $\mathrm{ND}(0.005)$ & $\mathrm{ND}(0.005)$ & $\mathrm{ND}(0.005)$ & $\mathrm{ND}(0.005)$ & $\mathrm{ND}(0.005)$ & $\mathrm{ND}(0.005)$ \\
\hline Phe & 0.009 & 0.163 & 0.011 & 0.232 & $\mathrm{ND}(0.005)$ & 0.061 \\
\hline Ant & $\mathrm{ND}(0.005)$ & 0.006 & $\mathrm{ND}(0.005)$ & 0.011 & $\mathrm{ND}(0.005)$ & $\mathrm{ND}(0.005)$ \\
\hline Flut & $\mathrm{ND}(0.005)$ & 0.025 & 0.005 & 0.171 & $\mathrm{ND}(0.005)$ & 0.023 \\
\hline Pyr & $\mathrm{ND}(0.005)$ & 0.020 & $\mathrm{ND}(0.005)$ & 0.181 & $\mathrm{ND}(0.005)$ & 0.022 \\
\hline $\mathrm{BaA}^{*}$ & $\mathrm{ND}(0.005)$ & $\mathrm{ND}(0.005)$ & $\mathrm{ND}(0.005)$ & $\mathrm{ND}(0.005)$ & $\mathrm{ND}(0.005)$ & $\mathrm{ND}(0.005)$ \\
\hline Chry* & $\mathrm{ND}(0.005)$ & $\mathrm{ND}(0.005)$ & $\mathrm{ND}(0.005)$ & 0.006 & $\mathrm{ND}(0.005)$ & $\mathrm{ND}(0.005)$ \\
\hline $\mathrm{BbFA} *$ & $\mathrm{ND}(0.005)$ & $\mathrm{ND}(0.005)$ & $\mathrm{ND}(0.005)$ & $\mathrm{ND}(0.005)$ & $\mathrm{ND}(0.005)$ & $\mathrm{ND}(0.005)$ \\
\hline BkFA * & $\mathrm{ND}(0.005)$ & $\mathrm{ND}(0.005)$ & $\mathrm{ND}(0.005)$ & $\mathrm{ND}(0.005)$ & $\mathrm{ND}(0.005)$ & $\mathrm{ND}(0.005)$ \\
\hline $\mathrm{BaP} * * *$ & $\mathrm{ND}(0.005)$ & $\mathrm{ND}(0.005)$ & $\mathrm{ND}(0.005)$ & $\mathrm{ND}(0.005)$ & $\mathrm{ND}(0.005)$ & $\mathrm{ND}(0.005)$ \\
\hline $\operatorname{DahA} * *$ & $\mathrm{ND}(0.005)$ & $\mathrm{ND}(0.005)$ & $\mathrm{ND}(0.005)$ & $\mathrm{ND}(0.005)$ & $\mathrm{ND}(0.005)$ & $\mathrm{ND}(0.005)$ \\
\hline BghiP & $\mathrm{ND}(0.005)$ & $\mathrm{ND}(0.005)$ & $\mathrm{ND}(0.005)$ & 0.006 & $\mathrm{ND}(0.005)$ & $\mathrm{ND}(0.005)$ \\
\hline $\mathrm{IP} *$ & $\mathrm{ND}(0.005)$ & $\mathrm{ND}(0.005)$ & $\mathrm{ND}(0.005)$ & $\mathrm{ND}(0.005)$ & $\mathrm{ND}(0.005)$ & $\mathrm{ND}(0.005)$ \\
\hline$\Sigma_{16} \mathrm{PAH} \mathrm{MB}^{2}$ & 0.060 & 2.045 & 0.057 & 1.507 & 0.101 & 2.539 \\
\hline $\mathrm{LB} / \mathrm{UB}^{2}$ & $0.02 / 0.10$ & $1.90 / 2.07$ & $0.02 / 0.09$ & $1.49 / 1.52$ & $0.07 / 0.14$ & $2.51 / 2.57$ \\
\hline$\Sigma 7$ Carc. MB & 0.018 & 0.018 & 0.018 & 0.021 & 0.018 & 0.018 \\
\hline LB/UB & $0 / 0.04$ & $0 / 0.04$ & $0 / 0.04$ & $0.006 / 0.04$ & $0 / 0.04$ & $0 / 0.04$ \\
\hline BaP-EQ US-EPA ${ }^{3}$ MB & 0.006 & 0.006 & 0.006 & 0.006 & 0.006 & 0.006 \\
\hline BaP-EQ N\&L ${ }^{4} \mathrm{MB}$ & 0.016 & 0.018 & 0.016 & 0.018 & 0.016 & 0.019 \\
\hline
\end{tabular}

Notes: *-carcinogenic $2 \mathrm{~B},{ }^{* *}$-carcinogenic $2 \mathrm{~A},{ }^{* * *}$-carcinogenic $1 .{ }^{1} \mathrm{ND}-$ non-detected, (EQL)—Estimated Quantification Level. ${ }^{2}$ LB-Lower-Bound (ND = 0), MB-Medium-Bound (ND = EQL/2), UB-Upper Bound (ND $=\mathrm{EQL}) .{ }^{3}[101],{ }^{4}$ [98], BA—bottom ash (Table 3), FA—fly ash (Table 3).

\subsection{Conformity of PCDD/Fs and PAHs in Ashes with the Proposed Limits for Fertilizers}

In view of the proposed limits of contamination in ashes to be used as fertilizers [65], there are some concerns regarding the studied ashes.

While content of $\mathrm{Cl}$ in bottom ashes (BA) varies from $0.004-0.22 \%$, fly ash (FA) streams present $0.14-8.1 \% \mathrm{Cl}$, exceeding the recommended $\mathrm{Cl}$ limit of $3 \%$ in some cases.

The $\Sigma_{16}$ PAHs of fly ashes $(1.5-2.5 \mathrm{mg} / \mathrm{kg})$ and bottom ashes $(0.06-0.1 \mathrm{mg} / \mathrm{kg})$ comply with the proposed limit of $6 \mathrm{mg} / \mathrm{kg}$. In this case, the handling of ND data has no significant impact on the conformity evaluation.

Regarding PCDD/Fs, the fly ashes present contents between 789-24,052 ng/kg, corresponding to 35-1139 ng $\mathrm{WHO}_{2005}-\mathrm{TEQ} / \mathrm{kg}$, assuming the $\mathrm{MB}$ option for ND values. Even assuming the LB option for $\mathrm{ND}$, the values vary from $26-1139 \mathrm{ng} \mathrm{WHO}_{2005}-\mathrm{TEQ} / \mathrm{kg}$. This means that the fly ashes unequivocally exceed the proposed limit of $20 \mathrm{ng} \mathrm{WHO}_{2005}-\mathrm{TEQ} / \mathrm{kg}$. In the case of bottom ashes, judgment on whether TEQs exceed the limit depends on the option used for ND. While for the MB option the TEQs range, 14-20 $\mathrm{ng} \mathrm{WHO}_{2005}-\mathrm{TEQ} / \mathrm{kg}$, indicate that bottom ashes may reach the limit; considering LB option (0-7.3 ng $\mathrm{WHO}_{2005}-\mathrm{TEQ} / \mathrm{kg}$ ) they comply, but considering the UB option (27-32 $\left.\mathrm{ng} \mathrm{WHO}_{2005}-\mathrm{TEQ} / \mathrm{kg}\right)$ all bottom ashes exceed the limit. This highlights the need for the requirement of low detection limits for such measurements.

The sensitivity analysis reveals that when there are left-censored data, the chosen options for handling ND results affect the judgment of compliance with limit values. When there are many ND cases, as in this study, the assignment of EQL fractions to ND is perhaps questionable [249]. Given the special case of PCDD/Fs, choice of another analytical methodology or laboratory could be advisable, in view of the target values and sample matrix. It becomes evident that any regulation of contaminants must detail requirements of analytical methodologies, namely sensitivity/detection limit and criteria to present results, including how to handle ND values. This is especially important when limit values are aggregated quantities such as TEQs and sum $(\Sigma)$. Other ND handling methods could be 
used, for example, involving statistical approaches, although this would require a deep knowledge of characteristic distribution of congeners/compounds, for each matrix/source based in data analysis. While there are no specifications, the MB attribution to ND appears to be an acceptable choice as a mid-term approach. Similar to the control of PCDDs/Fs in food, the less conservative (LB) or more precautionary (UB) results should be included in reports, as well as criteria for differences between LB and UB. Research activities and risk assessment works should also observe these critical issues, so that experimental results may represent valuable sources of data to support regulation activities and protect the environment and human life.

Although contents of $\mathrm{Cl}, \mathrm{C}$ and PAHs in ashes are important for PCDD/Fs formation, other mechanisms may be important, such as the presence of precursors and pre-existing PCDD/Fs. Thus, neither $\mathrm{C}, \mathrm{Cl}$ or any other parameter, should be assumed as pre-indicators for $\mathrm{PCDD} / \mathrm{Fs}$ analysis. This analysis of PCDD/Fs must be mandatory and the same applies for dl-PCBs already incorporated in TEQs, or other highly toxic POPs. However, a balance between frequency of measurements and the cost of monitoring requirements need to be considered. One option might be the use of accredited effect-based bioassays used for monitoring PCDD/Fs, such as DRCALUX or CALUX ${ }^{\circledR}$ Bioassay, which are considerably cheaper. The selectivity of these assays for dioxin-like compounds and interference of PAHs can be overcome by appropriate clean-up, and by this can be used for soils and sediments [250] and ashes [251].

The contamination of ashes is affected by mixes: bottom ashes and fly ashes may contain other flows produced in different zones, such as superheaters, economizers, cyclones, baghouses and ESP, which was also highlighted elsewhere [143]. This is another important subject to be addressed in fertilizer regulations, for example, the definition of the constitution of ash streams that may be used as fertilizers.

The provenience of ashes must also be better defined; the simple designation as "biomass ashes" as a corollary for safe use appears to be inadequate. Ashes from residual biomass originated in field plague control, wood and food industries, agriculture, farming, or other types of biomass/bio-residues, such as sludges, compost and organic fractions of MSW, may exhibit much higher contamination than natural biomass ashes. Besides POPs and their precursors, possible contamination of fuels with toxic and bioaccumulative metals $(\mathrm{Cd}, \mathrm{Pb}, \mathrm{Hg}$, As, etc.) results in higher contents of these metals in ashes. Furthermore, metals like $\mathrm{Cu}$ may have a memory effect along the furnace systems, catalyzing PCDD/Fs formation for prolonged periods.

\section{Conclusions}

This work aimed at contributing to a deeper understanding and knowledge on the risks of using biomass ashes as fertilizers, and the need to incorporate sustainable principles in renewable bioenergy, namely preservation of forest ecosystems. This aim is within the scope of Circular Bioeconomy, and aligns with objectives of the incoming Roadmap on Chemicals Strategy for Sustainability of the European Green Deal, which highlights the need to strengthen regulations for greater protection of humans and wildlife from chemical mixtures, including the use of fertilizers.

Results obtained show that some ashes, in particular fly ashes, from combustion of residual forest biomass contain PCDD/Fs levels exceeding proposed limits for ash use as fertilizer. Hence, the fertilizer regulations must address these concerns, establishing safe limit for POPs values and detailing which ashes can be used. Also, definitions of analytical methodologies, frequency of measurements and reporting data are essential and should be specified in regulations.

Due to the complexity of formation and fate of PCDD/Fs and PAHs, more research is required to get a deeper understanding of the fate of PCDD/Fs and PAHs during residual biomass combustion, using different technologies. However, it became clear that either the nature of residual forest biomass, for example, containing concerning levels of $\mathrm{Cl}$, or presence of background levels of PCDD/Fs may originate contaminated ashes. 
The current Basel Convention "low POPs" content of 15,000 ng TEQ/kg is orders of magnitudes too high and could mislead the management of ashes. Even the proposed lower value of $1000 \mathrm{ng}$ $\mathrm{TEQ} / \mathrm{kg}$ is far too high for the use of ashes in soils $[7,8,252]$. Due to the increasing generation and use of ashes from biomass combustion/incineration, this should be clarified in Basel Convention not to mislead policy makers and owners of ashes to select the wrong end of life disposal options and contaminate soils with associated exposure risk.

The safety of utilization of ashes is a global issue since the use of biomass residues for energy production is growing worldwide. In many developing countries in Asia, Africa and South America, poor regulation of impacted waste wood and poor combustion technology may result in contaminated ashes that are spread in agricultural soils, with associated long term risk for human health from accumulation in livestock, including chicken/eggs. Also, the intensive household biomass combustion, if impacted wood or plastic is involved, can result in contaminated ashes, and if spread in the garden results in the contamination of soils with risks for chicken/eggs frequently kept around houses in developing countries. The Stockholm and Basel Conventions should therefore reinforce frameworks for developing regions to develop regulations for treated waste wood and facilitate clean biomass combustion, and effectively prevent dissemination and indiscriminate use of contaminated ashes as fertilizers. For this, appropriate PCDD/F limits, similarly to the recently developed limits in the EU or Germany, should also be promoted as a frame for a circular economy for this increasingly generated waste/material flow.

Author Contributions: H.L. is the researcher responsible for the study conceptualization, implementation of methodologies and execution/supervision of the experimental part relating the characterization of materials analyzed and writing the original draft and review. S.P. is the researcher responsible for the critical interpretation of results in view of their potential toxicity, sensitivity analysis to evaluate the impact of ND on risk assessment and compliance, writing the original draft and review. All authors have read and agreed to the published version of the manuscript.

Funding: This research was funded by Fundação para a Ciência e a Tecnologia (FCT), Portugal, in the scope of Competitiveness Factors Thematic Operational Programme (COMPETE) of the Community Support Framework III and by the European Community Fund FEDER, through the project (Bias-to-Soil) PTDC/AAC-AMB/098112/2008-FCOMP-01-0124-FEDER-00848. Susana Proença's Ph.D. is funded by the in 3 project-Marie Sklodowska-Curie Action-Innovative Training Network under grant no. 721975.

Acknowledgments: This work is dedicated to Mario Costa from IST-Lisbon, a relevant and inspiring researcher in the area of thermal use of fuels and pollution control. We acknowledge the IEA TCP-FBC, and especially Juchelkova Dagmar for the invitation and support to participate in this special issue. We also want to express our gratitude to the very valuable comments of the reviewers, which could significantly improve the article.

Conflicts of Interest: The authors declare no conflict of interest. The funders had no role in the design of the study; in the collection, analyses, or interpretation of data; in the writing of the manuscript, or in the decision to publish the results.

\section{References}

1. United Nations. Resolution Adopted by the General Assembly on 25 September 2015 70/1. Transforming Our World: The 2030 Agenda for Sustainable Development. Available online: https:/www.un.org/ en/development/desa/population/migration/generalassembly/docs/globalcompact/A_RES_70_1_E.pdf (accessed on 23 March 2020).

2. Regulation (EU) 2019/1021 of the European Parliament and of the Council of 20 June 2019. OJEU, European Union. L169/45-77, 25 June 2019.

3. Regulation (EC) No 850/2004 of the European Parliament and of the Council of 29 April 2004. OJEU, European Union. L158/7-49, 30 April 2004.

4. Protocol on Persistent Organic Pollutants (POPs). Available online: https://www.unece.org/env/lirtap/pops_ h1.html (accessed on 23 March 2020).

5. Stockholm Convention on Persistent Organic Pollutions (POPs). Available online: http://www.pops.int/ TheConvention/Overview/TextoftheConvention/tabid/2232/Default.aspx (accessed on 23 March 2020). 
6. Basel Convention on the Control of Transboundary Movements of Hazardous Wastes and their Disposal. Available online: http://www.basel.int/TheConvention/Overview/tabid/1271/Default.aspx (accessed on 23 March 2020).

7. Swedish EPA. Low POP Content Limit of PCDD/F in Waste. Evaluation of Human Health Risks; Report 6418; Swedish EPA: Bromma, Sweden, 2011; ISBN 978-91-620-6418.

8. Weber, R.; Bell, L.; Watson, A.; Petrlik, J.; Paun, M.C.; Vijgen, J. Assessment of POPs contaminated sites and the need for stringent soil standards for food safety for the protection of human health. Environ. Pollut. 2019, 249, 703-715. [CrossRef] [PubMed]

9. Petrlik, J.; Bell, L. PCDD/Fs in waste incineration fly ash. Organohalogen Compd. 2017, 79, 249-252.

10. Toolkit for Identification and Quantification of Releases of Dioxins, Furans and Other Unintentional POPs. Available online: http://toolkit.pops.int (accessed on 23 March 2020).

11. BATBEP-Guidelines on Best Available Techniques and Guidance on Best Environmental Practices. Available online: http://chm.pops.int/Implementation/BATandBEP/BATBEPGuidelinesArticle5/tabid/187/Default.aspx (accessed on 23 March 2020).

12. BREFs. Available online: https://eippcb.jrc.ec.europa.eu/reference (accessed on 23 March 2020).

13. Directive 2010/75/EU of the European Parliament and of the Council of 24 November 2010. OJEU, European Union. L334/17-119, 17 December 2010.

14. European Commission. Study for the Strategy for a Non-Toxic Environment of the 7th EAP. Sub-Study d: Very Persistent Chemicals. August 2017. Available online: https://ec.europa.eu/environment/chemicals/nontoxic/index_en.htm (accessed on 23 March 2020).

15. The European Green Deal COM (2019) 640 Final. Communication from the Commission to the European Parliament, the Council, the European Economic and Social Committee and the Committee of the Regions; European Commission: Luxembourg, 11 December 2019.

16. European Commission. Community strategy for dioxins, furans and polychlorinated biphenyls (2001/C 322/02). Communication from the Commission to the Council, the European Parliament and the Economic and Social Committee. OJEC C 322/2-18, 17 November 2001.

17. Weber, R.; Herold, C.; Hollert, H.; Kamphues, J.; Blepp, M.; Ballschmiter, K. Reviewing the relevance of dioxin and PCB sources for food from animal origin and the need for their inventory, control and management. Environ. Sci. Eur. 2018, 30,1-42. [CrossRef]

18. Ahlborg, U.G.; Brouwer, A.; Fingerhut, M.A.; Jacobson, J.L.; Jacobson, S.W.; Kennedy, S.W.; Kettrup, A.F.; Koeman, J.H.; Poiger, H.; Rappe, C.; et al. Impact of polychlorinated dibenzo-p-dioxins, dibenzofurans, and biphenyls on human and environmental health, with special emphasis on application of the toxic equivalency factor concept. Eur. J. Pharmacol. 1992, 228, 179-199.

19. Alcock, R.E.; Jones, K.C. Dioxins in the environment: A review of trend data. Environ. Sci. Technol. 1996, 30, 3133-3143. [CrossRef]

20. Code of Practice for the Prevention and Reduction of Dioxin and Dioxin-like PCB Contamination in Food and Feeds. Available online: http://www.fao.org/ag/againfo/home/en/news_archive/2009_IN_dioxin.html (accessed on 23 March 2020).

21. European POPs Expert Team; European Commission. Preparatory Actions in the Field of Dioxins and PCBs. Available online: https://ec.europa.eu/environment/archives/dioxin/pdf/prepactfinrept.pdf (accessed on 23 March 2020).

22. Commission Regulation (EC) No 1881/2006 of 19 December 2006. OJEU L, European Union, 364/5-24, 20 December 2006.

23. Commission Recommendation 2013/711/EU of 3 December 2013. OJEU L, European Union, 323/37-39, 4 December 2013.

24. IEA. World Energy Outlook 2019. Paris. Available online: https://www.iea.org/reports/world-energyoutlook-2019 (accessed on 23 March 2020).

25. World Energy Council. World Energy Resources 2016. London. Available online: https://www.worldenergy. org/assets/images/imported/2016/10/World-Energy-Resources-Full-report-2016.10.03.pdf (accessed on 23 March 2020).

26. van Loo, S.; Koppejan, J. The Handbook of Biomass Combustion and Co-Firing; Earthscan: London, UK, 2008. [CrossRef] 
27. Someshwar, A.V. Wood and combination wood-fired boiler ash characterization. J. Environ. Qual. 1996, 25, 962-972. [CrossRef]

28. Vassilev, S.V.; Baxter, D.; Andersen, L.K.; Vassileva, C.G. An overview of the composition and application of biomass ash. Part 1. Phase-mineral and chemical composition and classification. Fuel 2013, 105, 40-76. [CrossRef]

29. Vassilev, S.V.; Baxter, D.; Andersen, L.K.; Vassileva, C.G. An overview of the composition and application of biomass ash. Part 2. Potential utilisation, technological and ecological advantages and challenges. Fuel 2013, 105, 19-39. [CrossRef]

30. Pöykiö, R.; Rönkkömäki, H.; Nurmesniemi, H.; Perämäki, P.; Popov, K.; Välimäki, I.; Tuomig, T. Chemical and physical properties of cyclone fly ash from the grate-fired boiler incinerating forest residues at a small municipal district heating plant (6MW). J. Hazard. Mater. 2009, 162, 1059-1064. [CrossRef]

31. Lavric, E.D.; Konnov, A.A.; Ruyck, J. Dioxin levels in wood combustion-A review. Biomass Bioenergy 2004, 26, 115-145. [CrossRef]

32. Rohr, A.C.; Campleman, S.L.; Long, C.M.; Peterson, M.K.; Weatherstone, S.; Quick, W.; Lewis, A. Potential occupational exposures and health risks associated with biomass-based power generation. Int. J. Environ. Res. Public Health 2015, 12, 8542-8605. [CrossRef] [PubMed]

33. Atkins, A.; Bignal, K.L.; Zhou, J.L.; Cazier, F. Profiles of polycyclic aromatic hydrocarbons and polychlorinated biphenyls from the combustion of biomass pellets. Chemosphere 2010, 78, 1385-1392. [CrossRef] [PubMed]

34. Khan, A.A.; de Jong, W.; Jansens, P.J.; Spliethoff, H. Biomass combustion in fluidized bed boilers: Potential problems and remedies. Fuel Process. Technol. 2009, 90, 21-50. [CrossRef]

35. Pohlandt, K.; Marutzky, R. Concentration and distribution of polychlorinated dibenzo-p-dioxins (PCDD) and polychlorinated dibenzofurans (PCDF) in wood ash. Chemosphere 1994, 28, 1311-1314. [CrossRef]

36. IEA Bioenergy Task 32 Deliverable D7. Options for Increased Use of Ash from Biomass Combustion and Co-Firing; IEA Bioenergy, 2018. Available online: www.ieabioenergy.com (accessed on 25 January 2020).

37. Insam, H.; Knapp, B.A. Recycling of Biomass Ashes; Springer: Berlin/Heidelberg, Germany; Dordrecht, The Netherlands; London, UK; New York, NY, USA, 2011. [CrossRef]

38. Pitman, R. Wood ash use in forestry-A review of the environmental impacts. Forestry 2006, 79, 563-588. [CrossRef]

39. Lanzerstorfer, C. Chemical composition and physical properties of filter fly ashes from eight grate-fired biomass combustion plants. J. Environ. Sci. 2015, 30, 191-197. [CrossRef]

40. Nurmesniemi, H.; Mäkelä, M.; Pöykiö, R.; Manskinen, K.; Dahl, O. Comparison of the forest fertilizer properties of ash fractions from two power plants of pulp and paper mills incinerating biomass-based fuels. Fuel Process. Technol. 2012, 104, 1-6. [CrossRef]

41. Dahl, O.; Nurmesniemi, H.; Pöykiö, R.; Watkins, G. Comparison of the characteristics of bottom ash and fly ash from a medium-size (32 MW) municipal district heating plant incinerating forest residues and peat in a fluidized-bed boiler. Fuel Process. Technol. 2009, 90, 871-878. [CrossRef]

42. Singh, S.; Ram, L.C.; Masto, R.E.; Verma, S.K. A comparative evaluation of minerals and trace elements in the ashes from lignite, coal refuse, and biomass fired power plants. Int. J. Coal Geol. 2011, 87, 112-120. [CrossRef]

43. Maresca, A.; Krüger, O.; Herzel, H.; Adam, C.; Kalbe, U.; Astrup, T.F. Influence of wood ash pre-treatment on leaching behaviour, liming and fertilising potential. Waste Manag. 2019, 83, 113-122. [CrossRef] [PubMed]

44. Pugliese, S.; Jones, T.; Preston, M.D.; Hazlett, P.; Tran, H.; Basiliko, N. Wood ash as a forest soil amendment: The role of boiler and soil type on soil property response. Can. J. Soil Sci. 2014, 94, 621-634. [CrossRef]

45. Vamvuka, D.; Kakaras, E. Ash properties and environmental impact of various biomass and coal fuels and their blends. Fuel Process. Technol. 2011, 92, 570-581. [CrossRef]

46. Väätäinen, K.; Sirparanta, E.; Räisänen, M.; Tahvanainem, T. The costs and profitability of using granulated wood ash as a forest fertilizer in drained peatland forests. Biomass Bioenergy 2011, 35, 3335-3341. [CrossRef]

47. Shi, R.; Li, J.; Jiang, J.; Mehmood, K.; Liu, Y.; Xu, R.; Qian, W. Characteristics of biomass ashes from different materials and their ameliorative effects on acid soils. J. Environ. Sci. 2017, 55, 294-302. [CrossRef] [PubMed]

48. James, A.K.; Thring, R.W.; Helle, S.; Ghuman, H.S. Ash management review-Applications of biomass bottom ash. Energies 2012, 5, 3856-3873. [CrossRef]

49. Rey-Salgueiro, L.; Omil, B.; Merino, A.; Martínez-Carballo, E.; Simal-Gándara, J. Organic pollutants profiling of wood ashes from biomass power plants linked to the ash characteristics. Sci. Total Environ. 2016, 544, 535-543. [CrossRef] 
50. Masto, R.; Sarkar, E.; George, J.; Jyoti, K.; Dutta, P.; Ram, L. PAHs and potentially toxic elements in the fly ash and bed ash of biomass fired power plants. Fuel Process. Technol. 2015, 132, 139-152. [CrossRef]

51. Sarenbo, S. Wood ash dilemma-reduced quality due to poor combustion performance. Biomass Bioenergy 2009, 33, 1212-1220. [CrossRef]

52. Enell, A.; Fuhrman, F.; Lundin, L.; Warfvinge, P.; Thelin, G. Polycyclic aromatic hydrocarbons in ash: Determination of total and leachable concentrations. Environ. Pollut. 2008, 152, 285-292. [CrossRef]

53. Straka, P.; Havelcová, M. Polycyclic aromatic hydrocarbons and other organic compounds in ashes from biomass combustion. Acta Geodyn. Geomater. 2012, 9, 481-490.

54. Miles, K. Hog Fuel Boiler/Wood Ash Action Plan: Technical Report. Publication Number 01-04-008. Revised February 2004. Department of Ecology. Hazardous Waste \& Toxics Reduction Program. Washington State. Available online: https://fortress.wa.gov/ecy/publications/SummaryPages/0104008.html (accessed on 10 March 2020).

55. Bundt, M.; Krauss, M.; Blaser, P.; Wilcke, W. Forest fertilization with wood ash: Effect on the distribution and storage of polycyclic aromatic hydrocarbons (PAHs) and polychlorinated biphenyls (PCBs). J. Environ. Qual. 2001, 30, 1296-1304. [CrossRef] [PubMed]

56. Freire, F.; Lopes, H.; Tarelho, L.A.C. Critical aspects of biomass ashes utilization in soils: Composition, leachability, PAH and PCDD/F. Waste Manag. 2015, 46, 304-315. [CrossRef]

57. Gul, N.; Khan, B.; Khan, H.; Israr, M. Dioxin leaching risk assessment through selected soils by estimating distribution coefficient and breakthrough curves. Environ. Monit. Assess. 2018, 190, 1-7. [CrossRef] [PubMed]

58. Kim, Y.; Lee, D. Solubility enhancement of PCDD/F in the presence of dissolved humic matter. J. Hazard. Mater. 2002, B91, 113-127. [CrossRef]

59. Haglund, N. NT Technical Report 613-Guideline for Classification of Ash from Solid Biofuels and Peat Utilized for Recycling and Fertilizing in Forestry and Agriculture; Nordic Innovation Centre: Oslo, Norway, 2008; ISSN 0283-7234.

60. Košnář, Z.; Mercl, F.; Perná, I.; Tlustoš, P. Investigation of polycyclic aromatic hydrocarbon content in fly ash and bottom ash of biomass incineration plants in relation to the operating temperature and unburned carbon content. Sci. Total Environ. 2016, 563-564, 53-61. [CrossRef] [PubMed]

61. Johansson, I.; van Bavel, B. Levels and patterns of polycyclic aromatic hydrocarbons in incineration ashes. Sci. Total Environ. 2003, 311, 221-231. [CrossRef]

62. Standards and Guidelines for the Use of Wood Ash as a Liming Material for Agricultural Soils; Alberta Environment: Edmonton, AB, Canada, 2002; ISBN 0-7785-2281-4.

63. Decreto-Lei n. ${ }^{\circ}$ 103/2015, Diário da Républica, 1 a $^{a}$ série, N. ${ }^{\circ} 114$ de 15 de Junho de 2015. 3756-3788. Diário da Republica, 2015.

64. Regulation (EU) 2019/1009 of the European Parliament and of the Council of 5 June 2019. OJEU, European Union L170/1-127, 25 June 2019.

65. Huygens, D.; Saveyn, H.G.M.; Tonini, D.; Eder, P.; Sancho, L.D. Technical Proposals for Selected New Fertilising Materials under the Fertilising Products Regulation (Regulation (EU) 2019/1009)_Process and Quality Criteria, and Assessment of Environmental and Market Impacts for Precipitated Phosphate Salts \& Derivates, Thermal Oxidation Materials \& Derivates and Pyrolysis \& Gasification Materials; EUR 29841 EN; Publications Office of the European Union: Luxembourg, 2019; ISBN 978-92-76-09888-1. JRC117856. [CrossRef]

66. Van den Berg, M.; Birnbaum, L.S.; Denison, M.; de Vit, M.; Farland, W.; Feeley, M.; Fiedler, H.; Hakansson, H.; Hanberg, A.; Haws, L.; et al. The 2005 World Health Organization re-evaluation of human and mammalian toxic equivalency factors for dioxins and dioxin-like compounds. Toxicol. Sci. 2006, 93, 223-241. [CrossRef]

67. Safe, S.H. Development validation and problems with the toxic equivalency factor approach for risk assessment of dioxins and related compounds. J. Anim. Sci. 1998, 76, 134-141. [CrossRef]

68. Kutz, F.W.; Barnes, D.G.; Bottimore, D.P.; Greim, H.; Bretthauer, E.W. The International toxicity equivalency factor (I-TEF) method of risk assessment for complex mixtures of dioxins and related compounds. Chemosphere 1990, 20, 751-757. [CrossRef]

69. Pilot Study on International Information Exchange on Dioxins and Related Compounds; Report Number 178; August 1988 North Atlantic Treaty Organization: Committee on the Challenges of Modern Society. U.S. Government Printing Office 1988-516-002/80238: Washington, DC, USA, 1998. 
70. Van den Berg, M.; Birnbaum, L.; Bosveld, A.T.C.; Brunström, B.; Cook, P.; Feeley, M.; Giesy, J.P.; Hanberg, A.; Hasegawa, R.; Kennedy, S.W.; et al. Toxic equivalency factors (TEFs) for PCBs, PCDDs, PCDFs for humans and wildlife. Environ. Health Perspect. 1998, 106, 775-792. [CrossRef] [PubMed]

71. Kato, M.; Urano, K. Convenient substitute indices to toxic equivalent quantity for controlling and monitoring dioxins in stack gas from waste incineration facilities. Waste Manag. 2001, 21, 55-62. [CrossRef]

72. Leclerc, D.; Duo, L.D.; Vessey, M. Effects of combustion and operating conditions on PCDD/PCDF emissions from power boilers burning salt-laden wood waste. Chemosphere 2006, 63, 676-689. [CrossRef] [PubMed]

73. Moltó, J.; Font, F.; Gálvez, A.; Rey, M.D.; Pequenín, A. Analysis of dioxin-like compounds formed in the combustion of tomato plant. Chemosphere 2010, 78, 121-126. [CrossRef]

74. Moltó, J.; Font, R.; Gálvez, A.; Muñoz, M.; Pequenín, A. Emissions of Polychlorodibenzodioxin/Furans (PCDD/Fs), dioxin-like Polychlorinated Biphenyls (PCBs), Polycyclic Aromatic Hydrocarbons (PAHs), and volatile compounds produced in the combustion of pine needles and cones. Energy Fuels 2010, 24, 1030-1036. [CrossRef]

75. Fång, J.; Nyberg, E.; Bignert, A.; Bergman, Å. Temporal trends of polychlorinated dibenzo-p-dioxins and dibenzofurans and dioxin-like polychlorinated biphenyls in mothers' milk from Sweden, 1972-2011. Environ. Int. 2013, 60, 224-231. [CrossRef]

76. Luthardt, P.; Mayer, J.; Fuchs, J. Total TEQ emissions (PCDD/F and PCB) from industrial sources. Chemosphere 2002, 46, 1303-1308. [CrossRef]

77. Pan, Y.; Yang, L.; Zhou, J.; Liu, J.; Qian, G.; Ohtsuka, N.; Motegi, M.; Oh, K.; Hosono, S. Characteristics of dioxins content in fly ash from municipal solid waste incinerators in China. Chemosphere 2013, 92, 765-771. [CrossRef]

78. Sakurai, T.; Weber, R.; Ueno, S.; Nishino, J.; Tanaka, M. Relevance of coplanar PCBs for TEQ emission of fluidized bed incineration and impact of emission control devices. Chemosphere 2003, 53, 619-625. [CrossRef]

79. Elskens, M.; Pussemier, L.; Dumortier, P.; Van Langenhove, K.; Scholl, G.; Goeyens, L.; Focant, J.F. Dioxin levels in fertilizers from Belgium: Determination and evaluation of the potential impact on soil contamination. Sci. Total Environ. 2013, 454-455, 366-372. [CrossRef] [PubMed]

80. Hoogerbrugge, R.; Liem, A.K.D. How to handle non detects. Oganohalogen Compd. 2000, 45, 13-16.

81. Rouhani, S.; van Geel, A. Treatment of Non-Detects in the Los Alamos National Laboratory Natural Resource Damage Assessment. DOE Contract DE-EM0003939; Industrial Economics Incorporated: Cambridge, MA, USA, 2017.

82. Zeghnoun, A.; Pascal, M.; Fréry, N.; Sarter, H.; Falq, G.; Focant, J.F.; Eppe, G. Dealing with the non-detected and non-quantified data. The example of the serum dioxin data in the French dioxin and incinerators study. Organohalogen Compd. 2007, 69, 2288-2291.

83. Delistraty, D.A.; Laflamme, D.M. Influence of toxic equivalency factor scheme and method for treating non-detect values on soil dioxin levels. Toxicol. Environ. Chem. 2001, 80, 67-81. [CrossRef]

84. Delistraty, D.A.; Singleton, S.A. Dioxin toxic equivalent concentrations in wood ash. Toxicol. Environ. Chem. 2002, 83, 69-85. [CrossRef]

85. Commission Regulation (EU) 2017/771 of 3 May 2017. OJEU L, European Union, 115/ 22-42, 4 May 2017.

86. Commission Regulation (EU) 589/2014 of June 2014. European Union, 164/18-40, 3 June 2014.

87. National Council for Air and Stream Improvement, Inc. (NCASI). A Comprehensive Compilation and Review of Wood-Fired Boiler Emissions. Technical Bulletin No. 1013; National Council for Air and Stream Improvmenmt, Inc.: Research Triangle Park, NC, USA, 2013.

88. Hedman, B.; Näslund, M.; Marklund, S. Emission of PCDD/F, PCB, and HCB from combustion of firewood and pellets in residential stoves and boilers. Environ. Sci. Technol. 2006, 40, 4968-4975. [CrossRef]

89. Liu, G.; Zheng, M.; Liu, W.; Wang, C.; Zhang, B.; Gao, L.; Su, G.; Xiao, K.; Lv, P. Atmospheric emission of PCDD/Fs, PCBs, Hexachlorobenzene, and pentachlorobenzene from the coking industry. Environ. Sci. Technol. 2009, 43, 9196-9201. [CrossRef]

90. Neupert, D.M.; Thies, J.; Weis, H. Demands of effective PCDD/PCDF-analysis in environment and production control. Aims of an analytical laboratory to meet legal and toxicological requirements. Critical approach to detection limits. Chemosphere 1986, 15, 1099-1106. [CrossRef]

91. Pampanin, D.M.; Sydnes, M.O. Polycyclic Aromatic Hydrocarbons a Constituent of Petroleum: Presence and Influence in the Aquatic Environment; 2013 Pampanin and Sydnes, licensee InTech; Available online: http: //creativecommons.org/licenses/by/3.0 (accessed on 26 April 2020). [CrossRef] 
92. Environmental Protection Agency. US-EPA, Code of Federal Regulation, Title 40, Part 60, subparts D, Da, Db, Dc; Environmental Protection Agency: Washington, DC, USA, 1997; p. 44.

93. CCME (Canadian Council of Ministers of the Environment). Canadian Soil Quality Guidelines for Carcinogenic and other Polycyclic Aromatic Hydrocarbons (Environmental and Human Health Effects). Scientific Supporting Document (218 pp); 2008; ISBN 978-1-896997-79-7. Available online: https://www.ccme.ca/files/Resources/ supporting_scientific_documents/pah_soqg_ssd_1401.pdf (accessed on 26 April 2020).

94. Working Group on Polycyclic Aromatic Hydrocarbons. Ambient Air Pollution by Polycyclic Aromatic Hydrocarbons (PAH); Position Paper; Office for Official Publications of the European Communities: Luxembourg, 2001; ISBN 92-894-2057-X.

95. Directive 2004/107/EC of the European Parliament and of the Council of 15 December 2004. OJEU L, European Union, 23/3-16, 26 January 2005.

96. International Agency for Research on Cancer; WHO. Agents Classified by the IARC Monographs. Volumes 1-125. Available online: https://monographs.iarc.fr/agents-classified-by-the-iarc/ (accessed on 6 March 2020).

97. Office of Research and Development. Provisional Guidance for Quantitative Risk Assessment of Polycyclic Aromatic Hydrocarbons; EPA/600/R-93/089, July 1993; Office of Research and Development: Washington, DC, USA, 1993.

98. Nisbet, I.C.T.; Lagoy, P.K. Toxic Equivalency Factors (TEFs) for Polycyclic Aromatic Hydrocarbons (PAH)s. Regul. Toxicol. Pharmacol. 1992, 16, 290-300. [CrossRef]

99. Law, R.J.; Kelly, C.; Baker, K.; Jones, J.; McIntosh, A.D.; Moffat, C.F. Toxic equivalency factors for PAH and their applicability in shellfish pollution monitoring studies. J. Environ. Monit. 2002, 4, 383-388. [CrossRef]

100. Delistraty, D. Toxic equivalency factor approach for risk assessment of polycyclic aromatic hydrocarbons. Toxicol. Environ. Chem. 1997, 64, 81-108. [CrossRef]

101. Potency Factors for Carcinogenic Polycyclic Aromatic Hydrocarbons. Regional Screening Levels (RSLs)-User's Guide. May 2020. Available online: https://www.epa.gov/risk/regional-screening-levels-rslsusers-guide\#toxicity (accessed on 21 April 2020).

102. Jung, K.H.; Yan, B.; Chillrud, S.N.; Perera, F.P.; Whyatt, R.; Camann, D.; Kinney, P.L.; Miller, R.L. Assessment of Benzo(a)pyrene-equivalent carcinogenicity and mutagenicity of residential indoor versus outdoor polycyclic aromatic hydrocarbons exposing young children in New York City. Int. J. Environ. Res. Public Health 2010, 7 , 1889-1900. [CrossRef] [PubMed]

103. Ramírez, N.; Cuadras, A.; Rovira, E.; Marcé, R.M.; Borrull, F. Risk assessment related to atmospheric polycyclic aromatic hydrocarbons in gas and particle phases near industrial sites. Environ. Health Perspect. 2011, 119, 1110-1116. [CrossRef] [PubMed]

104. Bari, M.A.; Baumbach, G.; Kuch, B.; Scheffknecht, G. Wood smoke as a source of particle-phase organic compounds in residential areas. Atmos. Environ. 2009, 43, 4722-4732. [CrossRef]

105. Bari, M.A.; Baumbach, G.; Kuch, B.; Scheffknecht, G. Particle-phase concentrations of polycyclic aromatic hydrocarbons in ambient air of rural residential areas in southern Germany. Air Qual. Atmos. Health 2010, 3, 103-116. [CrossRef]

106. Schecter, A.; Birnbaum, L.; Ryan, J.J.; Constable, J.D. Dioxins: An overview. Environ. Res. 2006, 101, 419-428. [CrossRef]

107. Weber, R.; Tysklind, M.; Gaus, C. Dioxin-Contemporary and future challenges of historical legacies (editorial, dedicated to Otto Hutzinger). Environ. Sci. Pollut. Res. 2008, 15, 96-100. [CrossRef]

108. Weber, R.; Gaus, C.; Tysklind, M.; Johnston, P.; Forter, M.; Hollert, H.; Heinisch, E.; Holoubek, I.; Lloyd-Smith, M.; Masunaga, S.; et al. Dioxin- and POP-contaminated sites-Contemporary and future relevance and challenges. Environ. Sci. Pollut. Res. 2008, 15, 363-393. [CrossRef]

109. Weber, R.; Watson, A. Assessment of the PCDD/F fingerprint of the dioxin food scandal from bio-diesel in Germany and possible PCDD/F sources. Organohalogen Compd. 2011, 73, 400-403.

110. Olie, K.; Vermeulen, P.L.; Hutzinger, O. Chlorodibenzo-p-dioxins and chlorodibenzofurans are trace components of fly ash and flue gas of some municipal incinerators in the Netherlands. Chemosphere 1977, 6, 455-459. [CrossRef]

111. Tuppurainen, K.; Halonen, I.; Ruokojärvi, P.; Tarhanen, J.; Ruuskanen, J. Formation of PCDDs and PCDFs in municipal waste incineration and its inhibition mechanisms: A review. Chemosphere 1998, 36, 1493-1511. [CrossRef] 
112. Yasuhara, A.; Katami, T.; Shibamoto, T. Formation of PCDDs, PCDFs, and coplanar PCBs from incineration of various woods in the presence of chlorides. Environ. Sci. Technol. 2003, 37, 1563-1567. [CrossRef] [PubMed]

113. Wikström, E.; Ryan, S.; Touati, A.; Gullett, B.K. Key parameters for de novo formation of Polychlorinated Dibenzo-p-dioxins and Dibenzofurans. Environ. Sci. Technol. 2003, 37, 1962-1970. [CrossRef] [PubMed]

114. Stanmore, B.R. The formation of dioxins in combustion systems. Combust. Flame 2004, 136, 398-427. [CrossRef]

115. Tame, N.W.; Dlugogorski, B.Z.; Kennedy, E.M. Formation of dioxins and furans during combustion of treated wood. Prog. Energy Combust. Sci. 2007, 33, 384-408. [CrossRef]

116. Altarawneh, M.; Dlugogorski, B.Z.; Kennedy, E.M.; Mackie, J.C. Mechanisms for formation, chlorination, dechlorination and destruction of polychlorinated dibenzo-p-dioxins and dibenzofurans (PCDD/Fs). Prog. Energy Combust. Sci. 2009, 35, 245-274. [CrossRef]

117. Zhang, M.; Buekens, A. De novo synthesis of dioxins: A review. Int. J. Environ. Pollut. 2016, 60, 63-110. [CrossRef]

118. Gullett, B.K.; Lemieux, P.M.; Dunn, J.E. Role of combustion and sorbent parameters in prevention of polychlorinated dibenzo-pdioxin and polychlorinated dibenzofuran formation during waste combustion. Environ. Sci. Technol. 1994, 28, 107-118. [CrossRef]

119. Lustenhouwer, J.W.A.; Olie, K.; Hutzinger, O. Chlorinated Dibenzo- $p$-Dioxins and related compounds in incineratior effluents. Chemosphere 1980, 9, 501-522. [CrossRef]

120. Vogg, H.; Metzger, M.; Stieglitz, L. Recent findings on the formation and decomposition of PCDD/PCDF in municipal solid waste incineration. Waste Manag. Res. 1987, 5, 285-294. [CrossRef]

121. Bruce, K.R.; Beach, L.O.; Gullett, B.K. The role of gas-phase $\mathrm{Cl} 2$ in the formation of PCDD/PCDF during waste combustion. Waste Manag. 1991, 11, 97-102. [CrossRef]

122. Addink, R.; Olie, K. Mechanisms of formation and destruction of Polychlorinated Dibenzo-p-dioxins and Dibenzofurans in heterogeneous systems. Environ. Sci. Technol. 1995, 29, 1425-1435. [CrossRef] [PubMed]

123. Stieglitz, L.; Zwick, G.; Beck, J.; Bautz, H.; Roth, W. Carbonaceous particles in fly-ash-a source for the de-novo-synthesis of organochlorocompounds. Chemosphere 1989, 19, 283-290. [CrossRef]

124. Luthe, C.; Karidio, I.; Utloth, V. Dioxins formation in salt-laden power boilers a mass balance. Chemosphere 1998, 36, 231-249. [CrossRef]

125. Fängmark, I.; Van Bavel, B.; Marklund, S.; Strömberg, B.; Berge, N.; Rappe, C. Influence of combustion parameters on the formation of polychlorinated dibenzo-pdioxins, dibenzofurans, benzenes, and biphenyls and polyaromatic hydrocarbons in a pilot incinerator. Environ. Sci. Technol. 1993, 27, 1602-1610. [CrossRef]

126. Fängmark, I.; Strömberg, B.; Berge, N.; Rappe, C. Influence of postcombustion temperature profiles on the formation of PCDDs, PCDFs, PCBzs, and PCBs in a pilot incinerator. Environ. Sci. Technol. 1994, 28, 624-629. [CrossRef]

127. Hasselriis, F. Optimization of combustion conditions to minimize Dioxin Emissions. Waste Manag. Res. 1987, 5, 311-326. [CrossRef]

128. Everaert, K.; Baeyens, J. Correlation of PCDD/F emissions with operating parameters of municipal solid waste incinerators. J. Air Waste Manag. Assoc. 2001, 51, 718-724. [CrossRef]

129. Everaert, K.; Baeyens, J. The formation and emission of dioxins in large scale thermal process. Chemosphere 2002, 46, 439-448. [CrossRef]

130. Liu, G.; Jiang, X.; Wang, M.; Dong, S.; Zheng, M. Comparison of PCDD/F levels and profiles in fly ash samples from multiple industrial thermal sources. Chemosphere 2015, 133, 68-74. [CrossRef]

131. Huang, H.; Buekens, A. On the mechanisms of Dioxin formation in combustion process. Chemosphere 1995, 31, 4099-4117. [CrossRef]

132. Wikström, E.; Tysklind, M.; Marklund, S. Influence of variation in combustion conditions on the primary formation of chlorinated organic micropollutants during municipal solid waste combustion. Environ. Sci. Technol. 1999, 33, 4263-4269. [CrossRef]

133. Wang, L.-C.; Lee, W.-J.; Lee, W.-S.; Chang-Chien, G.-P.; Tsai, P.-J. Effect of chlorine content in feeding wastes of incineration on the emission of polychlorinated dibenzo-p-dioxinsydibenzofurans. Sci. Total Environ. 2003, 302, 185-198. [CrossRef]

134. Luijk, R.; Akkerman, D.M.; Slot, P.; Olie, K.; Kapteijn, F. Mechanism of formation of polychlorinated dibenzo-p-dioxines and dibenzofurans in the catalyzed combustion of carbon. Environ. Sci. Technol. 1994, 28, 312-321. [CrossRef] 
135. Stieglitz, L.; Zwick, G.; Beck, J.; Bautz, H.; Roth, W. The role of particulate carbon in the de-novo synthesis of polychlorinated Dibenzodioxins and -Furans in fly-ash. Chemosphere 1990, 20, 1953-1958. [CrossRef]

136. Olie, K.; Bueken, A. Comparison of PCDD/F profiles in combustion residues. Organohalogen Compd. 2007, 69, 2443-2446.

137. Chang, N.-B.; Huang, S.-H. A chemometric approach for the verification of dioxin/furan formation mechanism in municipal waste incinerators. Chemosphere 1996, 32, 209-216. [CrossRef]

138. Korucu, M.K.; Karademir, A. An evaluation of PCDD/F mass flux from a hazardous waste incinerator: The need for a reasonable start-up procedure. Combust. Sci. Technol. 2015, 187, 458-468. [CrossRef]

139. Lu, S.-Y.; Du, Y.; Yan, J.-H.; Li, X.D.; Ni, M.-J.; Cen, K.-F. Dioxins and their fingerprint in size-classified fly ash fractions from municipal solid waste incinerators in china-mechanical grate and fluidized bed units. J. Air Waste Manag. Assoc. 2012, 62, 717-724. [CrossRef]

140. Oehme, M.; Müller, M.D. Levels and congener patterns of polychlorinated Dibenzo-p-dioxins and Dibenzofurans in solid residues from wood-fired boilers. Influence of combustion conditions and fuel type. Chemosphere 1995, 30, 1527-1539. [CrossRef]

141. Vogg, H.; Stieglitz, L. Thermal Behavior of PCDD/PCDF in fly ash from municipal incinerators. Chemosphere 1986, 15, 1373-1378. [CrossRef]

142. Shen, H.-M.; Wang, Y.-F.; Chyang, C.-S.; Yang, H.-Y. Incineration of pelettized fly ash in a bench-scale fluidized bed combustor. Aerosol Air Qual. Res. 2019, 19, 2115-2129. [CrossRef]

143. Wunderli, S.; Zennegg, M.; Doležal, I.S.; Gujerb, E.; Moser, U.; Wolfensberger, M.; Hasler, P.; Nogera, D.; Studer, C.; Karlaganis, G. Determination of polychlorinated dibenzo-p-dioxins and dibenzo-furans in solid residues from wood combustion by HRGC/HRMS. Chemosphere 2000, 40, 641-649. [CrossRef]

144. Bacher, R.; Swerev, M.; Ballschmlter, K. Profile and pattern of Monochloro-through Octachlorodibenzodioxins and -dibenzofurans in chimney deposits from wood burning. Environ. Sci. Technol. 1992, 26, 1649-1655. [CrossRef]

145. Weber, R.; Hagenmaier, H. PCDD/PCDF formation in fluidized bed incineration. Chemosphere 1999, 38, 2643-2654. [CrossRef]

146. Bai, S.T.; Chang, S.H.; Duh, J.M.; Sung, F.H.; Su, J.S.; Chang, M.B. Characterization of PCDD/Fs and dioxin-like PCBs emitted from two woodchip boilers in Taiwan. Chemosphere 2017, 189, 284-290. [CrossRef] [PubMed]

147. Moreno, A.I.; Juan, R.F.; Conesa, J.A. Characterization of gaseous emissions and ashes from the combustion of furniture waste. Waste Manag. 2016, 58, 299-308. [CrossRef]

148. Wang, H.C.; Hwang, J.F.; Chi, K.H.; Chang, M.B. Formation and removal of PCDD/Fs in a municipal waste incinerator during different operating periods. Chemosphere 2007, 67, S177-S184. [CrossRef]

149. Chen, C.-K.; Lin, C.; Wang, L.-C.; Chang-Chien, G.-P. The size distribution of polychlorinated dibenzo-p-dioxins and dibenzofurans in the bottom ash of municipal solid waste incinerators. Chemosphere 2006, 65, 514-520. [CrossRef]

150. Weidemann, E.; Allegrini, E.; Astrup, T.F.; Hulgaard, T.; Ribe, C.; Jansson, S. Size fractionation of waste-to-energy boiler ash enables separation of a coarse fraction with low dioxin concentrations. Waste Manag. 2016, 49, 110-113. [CrossRef]

151. Wikström, E.; Ryan, S.; Touati, A.; Telfer, M.; Tabor, D.; Gullett, B.K. Importance of chlorine speciation on de Novo formation of polychlorinated Dibenzo-p-dioxins and Polychlorinated Dibenzofurans. Environ. Sci. Technol. 2003, 37, 1108-1113. [CrossRef]

152. Luthe, C.; Karidio, I.; Utloth, V. Towards controlling dioxins emissions from power boilers fuelled with salt-laden wood waste. Chemosphere 1997, 35, 557-574. [CrossRef]

153. Wikström, E.; Löfvenius, G.; Rappe, C.; Marklund, S. Influence of level and form of chlorine on the formation of chlorinated Dioxins, Dibenzofurans, and Benzenes during combustion of an artificial fuel in a laboratory reactor. Environ. Sci. Technol. 1996, 30, 1637-1644. [CrossRef]

154. Wikström, E.; Maklund, S. The influence of level and chlorine source on the formation of monoto octa-chlorinated dibenzo-p-dioxins, dibenzofurans and coplanar polychlorinated biphenyls during combustion of an artificial municipal waste. Chemosphere 2001, 43, 227-234. [CrossRef]

155. Duo, W.; Leclerc, D. Thermodynamic analysis and kinetic modelling of dioxin formation and emissions from power boilers firing salt-laden hog fuel. Chemosphere 2007, 67, S164-S176. [CrossRef]

156. Gullett, B.K.; Bruce, K.R.; Beach, L.O. The effect of metal catalyst on the formation of polychlorinated Dibenzo-p-dioxin and Polychlorinated Dibenzofuran Precursors. Chemosphere 1990, 20, 1945-1952. [CrossRef] 
157. Gullett, B.K.; Touati, A.; Lee, C.W. Formation of chlorinated dioxins and furans in a hazardous-waste-firing industrial boiler. Environ. Sci. Technol. 2000, 34, 2069-2074. [CrossRef]

158. Gullett, B.K.; Sarofim, A.F.; Smith, K.A.; Procaccini, C. The role of chlorine in Dioxin formation. Trans. IChemE 2000, 78, 47-52. [CrossRef]

159. Ryu, J.-Y.; Mulholland, J.A.; Dunn, J.E.; Iino, F.; Gullett, B.K. Potential role of chlorination pathways in PCDD/F formation in a municipal waste incinerator. Environ. Sci. Technol. 2004, 38, 5112-5119. [CrossRef]

160. Thomas, V.M.; Spiro, T.G. The U.S. Dioxin inventory: Are there missing sources? Environ. Sci. Technol. 1996, 30, 82A-85A. [CrossRef]

161. Lopes, H.; Gulyurtlu, I.; Abelha, P.; Crujeira, A.T.; Salema, D.; Freire, M.; Pereira, R.; Cabrita, I. Particulate and PCDD/F emissions from coal co-firing with solid biofuels in a bubbling fluidised bed reactor. Fuel 2009, 88, 2373-2384. [CrossRef]

162. Someshwar, A.V.; Jain, A.K.; Whittemore, R.C.; LaFleur, L.E.; Gillespie, W.J. The Effects of sludge burning on the PCDD/F content of ashes from pulp and paper mill hog fuel boilers. Chemosphere 1990, 20, 1715-1722. [CrossRef]

163. Duo, W.-L.; Uloth, V.; Karidio, I.; Leclerc, D.; Kish, J.; Singbeil, D. Experimental Study of Dioxin Formation and Emissions from Power Boilers Burning Salt-Laden Wood Waste; Paprican Technical Report, PSR 509; Paprican: Vancouver, BC, Canada, 2004.

164. Ogawa, H.; Orita, N.; Horaguchi, M.; Suzuki, T.; Okada, M.; Yasuda, S. Dioxin reduction by sulfur component addition. Chemosphere 1996, 32, 151-157. [CrossRef]

165. Gullett, B.K.; Dunn, J.E.; Raghunathan, K. Effect of cofiring coal on formation of polychlorinated dibenzo-p-dioxins and dibenzofurans during waste combustion. Environ. Sci. Technol. 2000, 34, 282-290. [CrossRef]

166. Raghunathan, K.; Gullett, B.K. Role of sulfur in reducing PCDD and PCDF Formation. Environ. Sci. Technol. 1996, 30, 1827-1834. [CrossRef]

167. Chang, M.B.; Cheng, Y.C.; Chi, K.H. Reducing PCDD/F formation by adding sulfur as inhibitor in waste incineration processes. Sci. Total Environ. 2006, 366, 456-465. [CrossRef]

168. Preto, F.; McCleave, R.; McLaughlin, D.; Wang, J. Dioxins/furans emissions from fluidized bed combustion of salt-laden hog fuel. Chemosphere 2005, 58, 935-941. [CrossRef]

169. Xie, W.; Liu, K.; Pan, W.-P.; Riley, J.T. Interaction between emissions of $\mathrm{SO}_{2}$ and $\mathrm{HCl}$ in fluidized bed combustors. Fuel 1999, 78, 1425-1436. [CrossRef]

170. Stieglitz, L.; Vogg, H. On formation conditions of PCDD/PCDF in fly ash from municipal waste incinerators. Chemosphere 1987, 16, 1917-1922. [CrossRef]

171. Lundin, L.; Gomez-Rico, M.F.; Forsberg, C.; Nordenskjöld, C.; Jansson, S. Reduction of PCDD, PCDF and PCB during co-combustion of biomass with waste products from pulp and paper industry. Chemosphere 2013, 91, 797-801. [CrossRef]

172. Aurell, J.; Fick, F.; Haglund, P.; Marklund, M. Effects of sulfur on PCDD/F formation under stable and transient combustion conditions during MSW incineration. Chemosphere 2009, 76, 767-773. [CrossRef]

173. Hunsinger, H.; Seifert, H.; Jay, K. Reduction of PCDD/F formation in MSWI by a process-integrated $\mathrm{SO}_{2}$ Cycle. Environ. Eng. Sci. 2007, 24, 1145-1159. [CrossRef]

174. Griffin, R.D. A new theory of dioxin formation in municipal solid waste combustion. Chemosphere 1986, 15, 1987-1990. [CrossRef]

175. Xie, Y.; Xie, W.; Liu, K.; Dicken, L.; Pan, W.-P.; Riley, J.T. The effect of sulfur dioxide on the formation of molecular chlorine during co-combustion of fuels. Energy Fuels 2000, 14, 597-602. [CrossRef]

176. Thomas, V.M.; McCreight, C.M. Relation of chlorine, copper and sulphur to dioxin emission factors. J. Hazard. Mater. 2008, 151, 164-170. [CrossRef] [PubMed]

177. Gullett, B.K.; Bruce, K.R.; Beach, L.O. Effect of sulfur dioxide on the formation mechanism of polychlorinated dibenzodioxin and dibenzofuran in municipal waste combustors. Environ. Sci. Technol. 1992, 26, 1938-1943. [CrossRef]

178. Ryan, S.P.; Li, X.-D.; Gullett, B.K.; Lee, C.W.; Clayton, M.; Touati, A. Experimental study on the effect of $\mathrm{SO}_{2}$ on PCDD/F emissions: Determination of the importance of gas-phase versus solid-phase reactions in PCDD/F formation. Environ. Sci. Technol. 2006, 40, 7040-7047. [CrossRef]

179. Skodras, G.; Pallada, A.; Kaldis, S.P.; Sakellaropoulos, G.P. Cleaner co-combustion of lignite-biomass-waste blends by utilising inhibiting compounds of toxic emissions. Chemosphere 2007, 67, S191-S197. [CrossRef] 
180. Ruokojärvi, P.H.; Asikainen, A.H.; Tuppurainen, K.A.; Ruuskanen, J. Chemical inhibition of PCDD/F formation in incineration processes. Sci. Total Environ. 2004, 325, 83-94. [CrossRef] [PubMed]

181. Samaras, P.; Blumenstock, M.; Lenoir, D.; Schramm, K.-W.; Kettrup, A. PCDD/F prevention by novel inhibitors: Addition of inorganic S- and N-compounds in the fuel before combustion. Environ. Sci. Technol. 2000, 34, 5092-5096. [CrossRef]

182. Zhan, M.-X.; Chen, T.; Fu, J.-Y.; Lin, X.-Q.; Lu, S.-Y.; Li, X.-D.; Yan, J.-H.; Buekens, A. High temperature suppression of dioxins. Chemosphere 2016, 146, 182-188. [CrossRef]

183. Lundin, L.; Jansson, S. The effects of fuel composition and ammonium sulfate addition on PCDD, PCDF, PCN and PCB concentrations during the combustion of biomass and paper production residuals. Chemosphere 2014, 94, 20-26. [CrossRef] [PubMed]

184. Pandelova, M.; Stanev, I.; Henkelmann, B.; Lenoir, D.; Schramm, K.-W. Correlation of PCDD/F and PCB at combustion experiments using wood and hospital waste. Influence of $\left(\mathrm{NH}_{4}\right)_{2} \mathrm{SO}_{4}$ as additive on PCDD/F and PCB emissions. Chemosphere 2009, 75, 685-691. [CrossRef] [PubMed]

185. Sánchez-Hervás, J.M.; Armesto, L.; Ruiz-Martínez, E.; Otero-Ruiz, J. PCDD/PCDF emissions from co-combustion of coal and PVC in a bubbling fluidised bed boiler. Fuel 2005, 84, 2149-2157. [CrossRef]

186. Addink, R.; Paulus, R.H.W.L.; Olie, K. Prevention of polychlorinated dibenzo-p-dioxins/dibenzofurans formation on municipal waste incinerator fly ash using nitrogen and sulfur compounds. Environ. Sci. Technol. 1996, 30, 2350-2354. [CrossRef]

187. Olie, K.; Addink, R.; Schoonenboom, M. Metals as catalysts during the formation and decomposition of chlorinated dioxins and furans in incineration processes. J. Air Waste Manag. Assoc. 1998, 48, 101-105. [CrossRef] [PubMed]

188. Hagenmaier, H.; Brunner, H.; Haag, R.; Kraft, M. Copper-catalyzed dechlorination/hydrogenation of polychlorinated dibenzo-p-dioxins, polychlorinated bibenzofurans, and other chlorinated aromatic compounds. Environ. Sci. Technol. 1987, 21, 1085-1088. [CrossRef]

189. Zhang, M.; Yang, J.; Buekens, A.; Olie, K.; Li, X. PCDD/F catalysis by metal chlorides and oxides. Chemosphere 2016, 159, 536-544. [CrossRef]

190. Fujimori, T.; Takaoka, M.; Takeda, N. Influence of $\mathrm{Cu}, \mathrm{Fe}, \mathrm{Pb}$, and $\mathrm{Zn}$ Chlorides and oxides on formation of chlorinated aromatic compounds in MSWI fly ash. Environ. Sci. Technol. 2009, 43, 8053-8059. [CrossRef]

191. Stieglitz, L.; Zwick, G.; Beck, J.; Roth, W.; Vogg, H. On the de-Novo synthesis of PCDD/PCDF on fly ash of municipal waste incinerators. Chemosphere 1989, 18, 1219-1226. [CrossRef]

192. Addink, R.; Altwicker, E.R. Role of copper compounds in the de Novo synthesis of polychlorinated dibenzo-p-dioxins/dibenzofurans. Environ. Eng. Sci. 1998, 15, 19-27. [CrossRef]

193. Qian, Y.; Zheng, M.; Liu, W.; Ma, X.; Zhang, B. Influence of metal oxides on PCDD/Fs formation from pentachlorophenol. Chemosphere 2005, 60, 951-958. [CrossRef] [PubMed]

194. Liu, W.; Zheng, M.; Zhang, B.; Qian, Y.; Ma, X.; Liu, W. Inhibition of PCDD/Fs formation from dioxin precursors by calcium oxide. Chemosphere 2005, 60, 785-790. [CrossRef] [PubMed]

195. Naikwadi, K.P.; Karasek, F.W. Prevention of PCDD formation in MSW incinerators by inhibition of catalytic activity of fly ash produced. Chemosphere 1989, 19, 299-304. [CrossRef]

196. Weber, R.; Sakurai, T.; Hagenmaier, H. Formation and destruction of PCDD/F during heat treatment of fly ash samples from fluidized bed incinerators. Chemosphere 1990, 38, 2633-2642. [CrossRef]

197. Naikwadi, K.P.; Albrecht, I.D.; Karasek, F.W. Mechanism of formation of PCDD/F in industrial waste incineration and a method of prevention of their formation. Chemosphere 1993, 27, 335-342. [CrossRef]

198. Potter, P.M.; Dellinger, B.; Lomnicki, S.M. Contribution of aluminas and aluminosilicates to the formation of PCDD/Fs on fly ashes. Chemosphere 2016, 144, 2421-2426. [CrossRef]

199. Altwicker, E.R.; Kumar, R.; Konduri, N.V.; Milligan, M.S. The role of precursors in formation of polychloro-dibenzo-p-dioxins and polychloro-dibenzofurans during heterogeneous combustion. Chemosphere 1990, 20, 1935-1944. [CrossRef]

200. Iino, F.; Imagawa, T.; Gullett, B.K. Dechlorination-Controlled Polychlorinated Dibenzofuran Isomer patterns from municipal waste incinerators. Environ. Sci. Technol. 2000, 34, 3143-3147. [CrossRef]

201. Oh, J.-E.; Touati, A.; Gullett, B.K.; Mulhollands, J.A. PCDD/F TEQ indicators and their mechanistic implications. Environ. Sci. Technol. 2004, 38, 4694-4700. [CrossRef] 
202. Collina, E.; Lasagni, M.; Pitea, D.; Keil, B.; Stieglitz, L. Degradation of octachlorodibenzofuran and octachlorodibenzo-p-dioxin spiked on fly ash: Kinetics and mechanism. Environ. Sci. Technol. 1995, 29, 577-585. [CrossRef]

203. Van Berkel, O.M.; Olie, K.; van den Berg, M. Thermal degradation of polychlorinated dibenzo- $p$-dioxins and polychlorinated dibenzofurans on fly ash from a municipal incinerator. Int. J. Environ. Anal. Chem. 1988, 34, 51-67. [CrossRef]

204. Fueno, H.; Tanaka, K.; Sugawa, S. Theoretical study of the dechlorination reaction pathways of octachlorodibenzo-p-dioxin. Chemosphere 2002, 48, 771-778. [CrossRef]

205. Ryu, J.-Y.; Choi, K.-C.; Mulholland, J.A. Polychlorinated dibenzo-p-dioxin (PCDD) and dibenzofuran (PCDF) isomer patterns from municipal waste combustion: Formation mechanism fingerprints. Chemosphere 2006, 65, 1526-1536. [CrossRef] [PubMed]

206. Cains, P.W.; Mccausland, L.J.; Fernandes, A.R.; Dyke, P. Polychlorinated dibenzo-p-dioxins and dibenzofurans formation in incineration: Effects of fly ash and carbon source. Environ. Sci. Technol. 1997, 31, 776-785. [CrossRef]

207. Weber, R.; Nagai, K.; Nishino, J.; Shiraishi, H.; Ishida, M.; Takasuga, T.; Konndo, K.; Hiraoka, M. Effects of selected metal oxides on the dechlorination and destruction of PCDD and PCDF. Chemosphere 2002, 46, 1247-1253. [CrossRef]

208. Weber, R.; Takasuga, T.; Nagai, K.; Shiraishi, H.; Sakurai, T.; Matuda, T.; Hiraoka, M. Dechlorination and destruction of PCDD, PCDF and PCB on selected fly ash from municipal waste incineration. Chemosphere 2002, 46, 1255-1262. [CrossRef]

209. Hagenmaier, H.; Kraft, M.; Brunner, H.; Haag, R. Catalytic effects of fly ash from waste incineration facilities on the formation and decomposition of polychlorinated dibenzo-p -dioxins and polychlorinated dibenzofurans. Environ. Sci. Technol. 1987, 21, 1080-1084. [CrossRef]

210. Yasuhara, A.; Tanaka, Y.; Katami, T.; Shibamoto, T. The role of metals in dioxin formation from combustion of newspapers and polyvinyl chloride in an incinerator. Chemosphere 2005, 58, 891-896. [CrossRef]

211. Murabayashi, M.; Moesta, H. Thermodynamic study on the reduction of the Polychlorinated Dibenzo-p -dioxins and dibenzofurans in incinerator exhausts. Environ. Sci. Technol. 1992, 26, 797-802. [CrossRef]

212. Chen, W.-S.; Shen, Y.-H.; Hsieh, T.-Y.; Lin, C.-W.; Wang, L.-C.; Chang-Chien, G.-P. Fate and distribution of polychlorinated dibenzo-p-dioxins and dibenzofurans in a woodchip-fuelled boiler. Aerosol Air Qual. Res. 2011, 11, 282-289. [CrossRef]

213. Wehrmeier, A.; Lenoir, D.; Schramm, K.W.; Zimmermann, R.; Hahn, K.; Henkelmann, B.; Kettrup, A. Patterns of isomers of chlorinated dibenzo-p-dioxins as a tool for elucidation of thermal formation mechanisms. Chemosphere 1998, 36, 2775-2801. [CrossRef]

214. Kopponen, P.; Törrönen, R.; Välttilä, O.; Talka, E.; Törrönem, J.; Ruuskanen, J.; Kärenlampi, S. Chemical and biological 2,3,7,8-tetrachlorodibenzo-p-dioxin equivalents in fly ash from combustion of bleached kraft pulp mill sludge. Environ. Toxicol. Chem. 1994, 13, 143-148. [CrossRef]

215. Wikström, E.; Maklund, S. Secondary formation of chlorinated dibenzo-p-dioxins, dibenzofurans, biphenyls, benzenes, and phenols during MSW combustion. Environ. Sci. Technol. 2000, 34, 604-609. [CrossRef]

216. Lima, A.L.C.; Farrington, J.W.; Reddy, C.M. Combustion-derived polycyclic aromatic hydrocarbons in the environment-A review. Environ. Forensics 2005, 6, 109-131. [CrossRef]

217. McGrath, T.; Sharma, R.; Hajaligol, M. An experimental investigation into the formation of polycyclic-aromatic hydrocarbons (PAH) from pyrolysis of biomass materials. Fuel 2001, 80, 1787-1797. [CrossRef]

218. Masclet, P.; Bresson, M.A.; Mouvier, G. Polycyclic aromatic hydrocarbons emitted by power stations, and influence of combustion conditions. Fuel 1987, 66, 556-562. [CrossRef]

219. Caneghem, J.V.; Vandecasteele, C. Characterisation of polycyclic aromatic hydrocarbons in flue gas and residues of a full scale fluidized bed combustor combusting non-hazardous industrial waste. Waste Manag. 2014, 34, 2407-2413. [CrossRef]

220. Liu, K.; Xie, W.; Zhao, Z.-B.; Pan, W.-P.; Riley, J.T. Investigation of polycyclic aromatic hydrocarbons in fly ash from fluidized bed combustion systems. Environ. Sci. Technol. 2000, 34, 2273-2279. [CrossRef]

221. Bignal, K.L.; Langridge, S.; Zhou, L.Z. Release of polycyclic aromatic hydrocarbons, carbon monoxide and particulate matter from biomass combustion in a wood-fired boiler under varying boiler conditions. Atmos. Environ. 2008, 42, 8863-8871. [CrossRef] 
222. Mastral, A.M.; Callén, M.S. A review on polycyclic aromatic hydrocarbon (PAH) emissions from energy generation. Environ. Sci. Technol. 2000, 34, 3051-3057. [CrossRef]

223. Janvijitsakul, K.; Kuprianov, V.I. Polycyclic aromatic hydrocarbons in coarse fly ash particles emitted from fluidized-bed combustion of thai rice husk. Asian J. Energy Environ. 2007, 8, 654-662.

224. Benfenati, E.; Mariani, G.; Fanelli, R.; Zucotti, S. De novo synthesis of PCDD, PCDF, PCB, PCN, and PAH in a pilot incinerator. Chemosphere 1991, 22, 1045-1052. [CrossRef]

225. Schoonenboom, M.H.; Olie, K. Formation of PCDDs and PCDFs from anthracene and chloroanthracene in a model fly ash system. Environ. Sci. Technol. 1995, 29, 2005-2009. [CrossRef] [PubMed]

226. Iino, F.; Imagawa, T.; Takeuchi, M.; Sadakata, M. De novo synthesis mechanism of polychlorinated dibenzofurans from polycyclic aromatic hydrocarbons and the characteristic isomers of polychlorinated naphthalenes. Environ. Sci. Technol. 1999, 33, 1038-1043. [CrossRef]

227. Iino, F.; Imagawa, T.; Takeuchi, M.; Sadakata, M.; Weber, R. Formation rates of polychlorinated dibenzofurans and dibenzo- $p$-dioxins from polycyclic aromatic hydrocarbons, activated carbon and phenol. Chemosphere 1999, 39, 2749-2756. [CrossRef]

228. Weber, R.; Iino, F.; Imagawa, T.; Takeuchi, M.; Sakurai, T.; Sadakata, M. Formation of PCDF, PCDD, PCB, and PCN in de novo synthesis from PAH: Mechanistic aspects and correlation to fluidized bed incinerators. Chemosphere 2001, 44, 1429-1438. [CrossRef]

229. Wilhelm, J.; Stieglitz, L.; Dinjus, E.; Will, R. Mechanistic studies on the role of PAHs and related compounds in PCDD/F formation on model fly ashes. Chemosphere 2001, 42, 797-802. [CrossRef]

230. Tarelho, L.A.C.; Lopes, M.H.S.D.; Silva, D.F.R.; Freire, M.S.M.; Teixeira, E.R.; Modolo, R.C.E. Characteristics of biomass used as fuel and ashes produced in two thermal power plants with BFBC. In Proceedings of the Proceedings Word Bioenergy 2014, Jonkoping, Sweden, 3-5 June 2014; ISBN 978-91-977624-8-9.

231. Vassilev, S.V.; Baxter, D.; Andersen, L.K.; Vassileva, C.G. An overview of the chemical composition of biomass. Fuel 2010, 89, 913-933. [CrossRef]

232. Obernberger, I.; Brunner, T.; Barnthaler, G. Chemical properties of solid biofuels-significance and impact. Biomass Bioenergy 2006, 30, 973-982. [CrossRef]

233. Pandelova, M.; Henkelmann, B.; Bussian, B.M.; Schramm, K.-W. Results of the second national forest soil inventory in Germany-Interpretation of level and stock profiles for PCDD/F and PCB in terms of vegetation and humus type. Sci. Total Environ. 2018, 610-611,1-9. [CrossRef]

234. Chen, P.; Mei, J.; Peng, P.; Hu, J.; Chen, D. Atmospheric PCDD/F concentrations in 38 cities of China monitored with pine needles, a passive biosampler. Environ. Sci. Technol. 2012, 46, 13334-13343. [CrossRef] [PubMed]

235. Baker, J.; Hites, R.A. Is combustion the major source of polychlorinated dibenzo- $p$-dioxins and dibenzofurans to the environment? A mass balance investigation. Environ. Sci. Technol. 2000, 34, 2879-2886. [CrossRef]

236. U.S. EPA. An Inventory of Sources and Environmental Releases of Dioxin-Like Compounds in the U.S. for the Years 1987, 1995, and 2000 (Final, Nov 2006); EPA/600/P-03/002F; U.S. Environmental Protection Agency: Washington, DC, USA, 2006.

237. Camenzuli, L.; Scheringer, M.; Gaus, C.; Grant, S.; Zennegg, M.; Hungerbühler, K. Historical emissions of octachlorodibenzodioxin in a watershed in Queensland, Australia: Estimation from field data and an environmental fate model. Sci. Total Environ. 2015, 502, 680-687. [CrossRef]

238. Holt, E.; Weber, R.; Stevenson, G.; Gaus, C. Formation of dioxins during exposure of pesticide formulations to sunlight. Chemosphere 2012, 88, 364-370. [CrossRef]

239. Prange, J.A.; Gaus, C.; Weber, R.; Päpke, O.; Müller, J.F. Assessing forest fire as a potential PCDD/F source in Queensland, Australia. Environ. Sci. Technol. 2003, 37, 4325-4329. [CrossRef] [PubMed]

240. Wagrowski, D.M.; Hites, R.A. Insights into the global distribution of polychlorinated dibenzo- $p$-dioxins and dibenzofurans. Environ. Sci. Technol. 2000, 34, 2952-2958. [CrossRef]

241. Hutzinger, O.; Blumich, M.J.; van den Berg, M.; Olie, M.K. Sources and fate of PCDDs and PCDFs: An overview. Chemosphere 1985, 14, 581-600. [CrossRef]

242. Pennise, D.M.; Kamens, R.M. Atmospheric behavior of polychlorinated dibenzo- $p$-dioxins and dibenzofurans and the effect of combustion temperature. Environ. Sci. Technol. 1996, 30, 2832-2842. [CrossRef]

243. Liu, K.; Pan, W.-P.; Riley, J.T. A study of chlorine in a simulated fluidised bed combustion system. Fuel 2000, 79, 1115-1124. [CrossRef]

244. Johansen, J.M.; Jakobsen, J.G.; Frandsen, F.J.; Glarborg, P. Release of K, Cl, and S during pyrolysis and combustion of high-chlorine biomass. Energy Fuels 2011, 25, 4961-4971. [CrossRef] 
245. Meij, R.; te Winkel, H. The emissions of heavy metals and persistent organic pollutants from modern coal-fired power stations. Atmos. Environ. 2007, 41, 9262-9272. [CrossRef]

246. Neuwahl, F.; Cusano, G.; Benavides, J.G.; Holbrook, S.; Roudier, S. Best Available Techniques (BAT) Reference Document for Waste Incineration; Publications Office of the European Union: Luxembourg, 2019. [CrossRef]

247. Abad, E.; Adrados, M.A.; Caixach, J.; Rivera, J. Dioxin abatement strategies and mass balance at a municipal waste management plant. Environ. Sci. Technol. 2002, 36, 92-99. [CrossRef] [PubMed]

248. Summoogum, S.L.; Altarawneh, M.; Mackie, J.C.; Kennedy, E.M.; Dlugogorski, B.Z. Oxidation of dibenzo-p-dioxin: Formation of initial products, 2-methylbenzofuran and 3-hydro-2-methylenebenzofuran. Combust. Flame 2012, 159, 3056-3065. [CrossRef]

249. Environmental Protection Agency. Assigning Values to Non-detected/Non-Quantified Pesticide Residues in Human Health Food Exposure Assessments, Office of Pesticide Programs, U.S.; Environmental Protection Agency: Washington, DC, USA, 2000.

250. US EPA, Office of Resource Conservation and Recovery. SW-846 Test Method 4435. Screening for Dioxin-Like Chemical Activity in Soils and Sediments using the CALUX Bioassay and Toxic Equivalents (TEQs) Determinations. Revision 1. July 2014. Test Methods for Evaluating Solid Waste, Physical/Chemical Methods; US EPA, Office of Resource Conservation and Recovery, 2014. Available online: https:/www.epa.gov/sites/production/files/ 2015-12/documents/4435.pdf. (accessed on 15 May 2020).

251. Behnisch, P.A.; Hosoe, K.; Shiozaki, K.; Kiryu, T.; Komatsu, K.; Schramm, K.W.; Sakai, S. Melting and incineration plants of municipal waste. Chemical and biochemical diagnosis of thermal processing samples (emission, residues). Environ. Sci. Pollut. Res. Int. 2002, 9, 337-344. [CrossRef] [PubMed]

252. General Technical Guidelines on the Environmentally Sound Management of Wastes Consisting of, Containing or Contaminated with Persistent Organic Pollutants. UNEP/CHW.14/7/Add.1/Rev.1. 20 June 2019. Available online: http://www.basel.int/TheConvention/ConferenceoftheParties/Callforinformation/FollowuptoCOP14/ tabid/8026/Default.aspx (accessed on 11 April 2020).

(C) 2020 by the authors. Licensee MDPI, Basel, Switzerland. This article is an open access article distributed under the terms and conditions of the Creative Commons Attribution (CC BY) license (http://creativecommons.org/licenses/by/4.0/). 